\title{
Review Article \\ Trophy Hunting, Conservation, and Rural Development in Zimbabwe: Issues, Options, and Implications
}

\author{
Victor K. Muposhi, ${ }^{1}$ Edson Gandiwa, ${ }^{1}$ Paul Bartels, ${ }^{2}$ and Stanley M. Makuza ${ }^{3}$ \\ ${ }^{1}$ School of Wildlife, Ecology and Conservation, Chinhoyi University of Technology, Private Bag 7724, Chinhoyi, Zimbabwe \\ ${ }^{2}$ Department of Nature Conservation, Tshwane University of Technology, Private Bag X680, Pretoria 0001, South Africa \\ ${ }^{3}$ School of Agricultural Sciences and Technology, Chinhoyi University of Technology, Private Bag 7724, Chinhoyi, Zimbabwe
}

Correspondence should be addressed to Victor K. Muposhi; vkmuposhi@gmail.com

Received 3 August 2016; Revised 22 November 2016; Accepted 23 November 2016

Academic Editor: Alexandre Sebbenn

Copyright (C) 2016 Victor K. Muposhi et al. This is an open access article distributed under the Creative Commons Attribution License, which permits unrestricted use, distribution, and reproduction in any medium, provided the original work is properly cited.

\begin{abstract}
Trophy hunting has potential to support conservation financing and contribute towards rural development. We conducted a systematic review of the Zimbabwean trophy hunting perspective spanning from pre-1890 to 2015, by examining the following: (1) evolution of legal instruments, administration, and governance of trophy hunting, (2) significance of trophy hunting in conservation financing and rural development, and (3) key challenges, emerging issues in trophy hunting industry, and future interventions. Our review shows that (i) there has been a constant evolution in the policies related to trophy hunting and conservation in Zimbabwe as driven by local and international needs; (ii) trophy hunting providing incentives for wildlife conservation (e.g., law enforcement and habitat protection) and rural communities' development. Emerging issues that may affect trophy hunting include illegal hunting, inadequate monitoring systems, and hunting bans. We conclude that trophy hunting is still relevant in wildlife conservation and rural communities' development especially in developing economies where conservation financing is inadequate due to fiscal constraints. We recommend the promotion of net conservation benefits for positive conservation efforts and use of wildlife conservation credits for the opportunity costs associated with reducing trophy hunting off-take levels and promoting nonconsumptive wildlife use options.
\end{abstract}

\section{Introduction}

Paleontological evidence suggests that hunting has always been part of the human societies since time immemorial [1, 2]. Hunting is considered as among other few human activities that show a more sustained link across human civilization [3]. However, unregulated hunting led to the extinction of some wildlife species through what has been referred to as the global blitzkrieg (overkill) hypothesis $[4,5]$ whilst the African continent was to some extent spared from this unprecedented loss of species [6]. This was possible because African communities practiced indigenous hunting practices [7], using some form of customary regulatory framework supported through an indigenous conservation practices (e.g., totems and norms) to reduce species loss. The overwhelming exploitation of wildlife species through hunting activities in the 19th century prompted people to instigate the protection of the remaining wildlife populations through various conservation initiatives [8]. This evolution resulted in the establishment of protected areas in most countries and the subsequent institutionalisation of trophy hunting as a conservation tool supported by ecological theory and sustainable use principles [9-11].

Trophy hunting refers to hunting by paying tourists, typically with the objective of selecting individuals with exceptional phenotypic traits (e.g., large horns, tusks, body size, mane, or skull length) and usually in the company of a professional hunting guide [12]. Trophy hunting uses a quota system approach that promotes sustainable off-takes by removing a fraction of natural population growth rates, which arguably falls within the compensatory mortality range and has a negligible impact on overall ecology of wildlife species [13, 14]. The quota system used in trophy hunting is based on ecological theory, that is, maximum sustainable yield (MSY), set 
in such a way that off-take levels are always below the growth rate of the target species at any given time $[11,15,16]$. However, there are concerns that over time trophy hunting may lead to loss of species if not properly regulated [17]. Some researchers argue that, by its nature, trophy hunting is meant to remove only a few individuals, mostly those that have past their prime reproductive time and as such should not compromise the viability of wildlife species [18-20]. Trophy hunting may contribute immensely to wildlife conservation and rural development if proper institutional and governance structures are in place to uphold the founding principles [3].

Research has shown that trophy hunting is known to create incentives for the conservation of threatened and endangered species as well as their habitats [21-24] and is considered as a market-based intervention to conservation in most countries endowed with diverse wildlife resources [25, 26]. The Convention on Biological Diversity (CBD) considers conservation to be largely characterized by sustainable utilization of resources for rural development under which the trophy hunting concept falls $[27,28]$. Trophy hunting as a form of sustainable use is a strong economic instrument that not only incentivizes conservation but also contributes to rural development through integrated conservation and development projects (ICDP) in most tropical countries [6, $29,30]$. For example, in Zimbabwe, the trophy hunting industry grew rapidly upon its inception of in the 1980s in marginalized and vulnerable communities in Communal Area Management Programme for Indigenous Resources (CAMPFIRE) areas as well as protected areas [31-33]. Nonetheless, the trophy hunting industry took a massive slump after the year 2000 due to the land acquisition and reform programme which resulted in the loss of wildlife in most private land where trophy hunting was previously practiced [34]. The industry has somewhat recovered but is also being affected by the restrictive policies by the United States of America and some European countries limiting the importation of some trophy specimens by hunters [35].

There is however perpetual debate, polarisation, and lack of consensus among conservation nongovernmental organizations, some African governments, and animal rights and welfare groups over the acceptability and effectiveness of trophy hunting as a conservation tool $[3,12,36]$. Arguments brought forward against trophy hunting include the continual decline of key wildlife species due to illegal hunting $[37,38]$, land reforms $[39,40]$, and negative media framing of wildlife conservation and trophy hunting [41-43], as well as unethical and immoral practices $[26,44]$. More so, there has been a rise in a globally polarised and emotive media discourse on animal welfare issues and the significance of trophy hunting following the illegal killing of "Cecil" a radio-collared lion (Panthera leo) by an American trophy hunting client in western Zimbabwe in 2015 [35, 45]. Similar responses from the international community occurred early 2015 in response to a legal hunt of a critically endangered male black rhinoceros (Diceros bicornis) in Namibia triggering motions for the outright ban in trophy hunting throughout Africa [46].

The United States Fish and Wildlife Service sanctioned a temporal ban on the importation of trophy products of the African elephant (Loxodonta africana), a key trophy hunting species from Zimbabwe, as of 2014 into the United States of America (https://www.fws.gov) [48]. Similarly, some commercial airlines adopted policies that do not allow freight of trophy products from certain species making it even more difficult for potential tourist hunters to fulfil their quest for having trophies from Africa [46]. Such policies have reduced the attractiveness of Zimbabwe as a trophy hunting destination given that a substantial number of trophy hunting clients interested in big game are known to originate from the United States of America. However, other researchers argue these restrictive policies and proposed trophy hunting bans may exacerbate the loss of wildlife species in most African countries due to the growing human population and competing priorities particularly on land use options [35, 46]. In Zimbabwe, trophy hunting is believed to offer incentives for conservation and habitat protection and rural development through ICDPs, that is, CAMPFIRE [29]. Banning trophy hunting may result in the demise of wildlife species as there would be little incentives and motivation to protect and conserve wildlife species and their habitats $[46,49]$.

Given the polarity and emotive nature of trophy hunting issues in modern-day conservation, more research is needed to inform policy at local, regional, and international levels. Considering that most international policies are implemented by member countries, research on the sustainability of trophy hunting as a conservation tool would aid in adaptive management processes particularly in countries endowed with diverse wildlife resources that are financially constrained to protect and conserve the vast wildlife habitats. This study focuses on trophy hunting and conservation issues using Zimbabwe as a case study. We specifically explored the following: (1) evolution of policy and legal instruments governing trophy hunting, (2) trophy hunting administration and governance, (3) significance of trophy hunting in conservation financing and rural development, and (4) emerging issues in trophy hunting industry and future interventions.

\section{Methods}

2.1. Research Approach. In this study, we adopted a holistic and historical perspective approach [41], to understand the linkages between trophy hunting, conservation, and rural development. A holistic approach enabled us to explore the issues emerging from trophy hunting as a conservation tool and how it contributes to community development and rural development. On the other hand, a historical perspective allowed us to explore the evolution of wildlife conservation and related institutional and policies frameworks that affect trophy hunting as a practice in Zimbabwe. Most scientific articles, reports, and written documents on trophy hunting issues in Zimbabwe are either old or outdated for a fluid and dynamic landscape of wildlife conservation. To fill this gap, we incorporated stakeholders and expert opinion on trophy hunting and wildlife conservation in Zimbabwe to disentangle the policy and governance issues, emerging issues, and challenges related to trophy hunting locally, regionally and globally. For this, we adopted four forms of ecological knowledge as described by Fleischman and Briske [47], that is, Scientific Ecological Knowledge (SEC), Local Ecological 
TABLE 1: The four forms of knowledge used for the key informant interviews. Adopted from Fleischman and Briske [47].

\begin{tabular}{lllll}
\hline & $\begin{array}{l}\text { Scientific Ecological } \\
\text { Knowledge }\end{array}$ & $\begin{array}{l}\text { Local } \\
\text { Ecological Knowledge }\end{array}$ & $\begin{array}{l}\text { Administrative or } \\
\text { Bureaucratic Knowledge }\end{array}$ & $\begin{array}{l}\text { Professional Ecological } \\
\text { Knowledge }\end{array}$ \\
\hline $\begin{array}{l}\text { Possessors of } \\
\text { knowledge }\end{array}$ & $\begin{array}{l}\text { Research scientists, } \\
\text { educators, technical } \\
\text { specialists }\end{array}$ & $\begin{array}{l}\text { Local resource users, } \\
\text { managers, service providers }\end{array}$ & $\begin{array}{l}\text { Government officials and } \\
\text { bureaucrats }\end{array}$ & $\begin{array}{l}\text { Agency professionals at } \\
\text { multiple levels }\end{array}$ \\
\hline $\begin{array}{l}\text { Origin of } \\
\text { knowledge }\end{array}$ & Systematic inquiry & $\begin{array}{l}\text { Experience with resource, } \\
\text { cultural tradition }\end{array}$ & $\begin{array}{l}\text { Administrative procedure and } \\
\text { actions }\end{array}$ & $\begin{array}{l}\text { Agency mission, regulation, } \\
\text { technical guides, procedures }\end{array}$ \\
\hline $\begin{array}{l}\text { Knowledge } \\
\text { content }\end{array}$ & $\begin{array}{l}\text { Ecosystem variables, } \\
\text { parameters, responses }\end{array}$ & $\begin{array}{l}\text { Ecosystem capacity to support } \\
\text { livelihoods }\end{array}$ & $\begin{array}{l}\text { Decision making for public } \\
\text { interest }\end{array}$ & $\begin{array}{l}\text { Best management practices, } \\
\text { resource use regulations }\end{array}$ \\
\hline $\begin{array}{l}\text { Sources of } \\
\text { feedback }\end{array}$ & $\begin{array}{l}\text { Hypothesis testing, peer } \\
\text { review, conference and } \\
\text { public critique }\end{array}$ & $\begin{array}{l}\text { Observation, human } \\
\text { well-being, cultural } \\
\text { persistence }\end{array}$ & $\begin{array}{l}\text { Legal proceedings, public } \\
\text { hearings }\end{array}$ & $\begin{array}{l}\text { Legal proceedings, public } \\
\text { critique }\end{array}$ \\
\hline
\end{tabular}

Knowledge (LEC), Administrative/Bureaucratic Knowledge $(\mathrm{BEK})$, and Professional Ecological Knowledge (PEK), to select respondents for experts' opinion (Table 1).

2.2. Data Collection and Analysis. We used a qualitative orientation approach [55] to conduct a meta-analysis of existing literature from peer-reviewed journal articles, books, edited book chapters, academic theses, and reports covering issues on wildlife conservation policy, trophy hunting, conservation financing, and rural development. We searched for materials from two main sources, namely, (1) internal and external reports from stakeholders (Zimbabwe Parks and Wildlife Management Authority (ZPWMA)), CAMPFIRE, World Wide Fund for Nature (WWF), African Wildlife Foundation (AWF), and technical reports, (2) peer-reviewed journal articles, books, edited book chapters, and academic theses from Google Scholar, Scopus, and Web of Science. The following key words or phrases were used: "trophy hunting, sport hunting, tourist hunting"; "wildlife conservation policy"; "conservation financing"; "CAMPFIRE"; "conservation and rural development"; "trophy hunting bans", and with a combination of "AND" between the key words to retrieve the relevant literature. From the articles gathered, we further mined for old articles discussing trophy hunting, wildlife conservation, and rural development. We ensured the search was fairly exhaustive though some studies may have fallen outside our search parameters, those that are published in lesser known volumes, or have not been cited in recent literature [56].

Only articles with abstracts containing at least two of the key words/phrases were selected. We later read documents to check if they discussed trophy hunting issues in relation to conservation and rural development. Accordingly, we reviewed a total of 350 articles including reports from which 153 were used in this paper. We conducted a metaanalysis using these publications and reports under the four themes: (1) evolution of legal instruments governing trophy hunting, (2) trophy hunting administration and governance, (3) significance of trophy hunting in conservation financing and rural development, and (4) emerging issues in trophy hunting industry and future interventions. For triangulation purposes and to augment literature sources, we conducted interviews with key informants across the four forms of ecological knowledge through snowball sampling. Through the snowball sampling technique, we were able to interview hard-to-reach subject experts on trophy hunting and wildlife conservation issues in Zimbabwe across the four forms of knowledge. In total, 20 interviews were conducted to gather empirical expert opinion on trophy hunting issues, threats, and future interventions between the period October 2015 and April 2016. The findings obtained here could be generalized to the regional context because the pool of data and experiences spilled beyond national boundaries.

We also acquired data on (1) elephant population trends for the period 1989-2014 [41,57] and (2) CAMPFIRE revenue data for the period 1989-2013 [41,53] from published sources. We performed simple linear regression analyses using IBM SPSS 20 software package (IMB, New York, USA) to determine trends in elephant population in Zimbabwe between 1989 and 2014.

\section{Results and Discussion}

\subsection{Evolution of Policy and Legal Instruments Governing} Trophy Hunting in Zimbabwe. Like most African countries, Zimbabwe's conservation landscape has evolved following three main phases, that is, precolonial (before 1890), colonial (1890-1979), and postcolonial (1980 to date) [7, 58]. During the precolonial era, trophy hunting was nonexistent as hunting was mainly for subsistence and was controlled through traditional institutions with a collective access ideology [59-62]. Although meat constituted a significant part of local diets, with wildlife products being essential commodities, technological limitations and unsophisticated weapons ensured that indigenous hunter gatherers did not deplete existing wildlife populations [7]. Generally, the precolonial era was characterized by indigenous conservation laws, totemism and sacred realm, and collective access ideologies as governed by traditional institutions (Figure 1).

The change in the political landscape through the colonial era transformed the collective access of indigenous communities into a highly restrictive and segregatory policy popularly known as fortress conservation [52, 63]. The fortress ideology resulted in the dispossession and displacement of indigenous people from their ancestral land and alienated them from the resources they were much dependent upon $[64,65]$. The colonial era led to the development of nature 


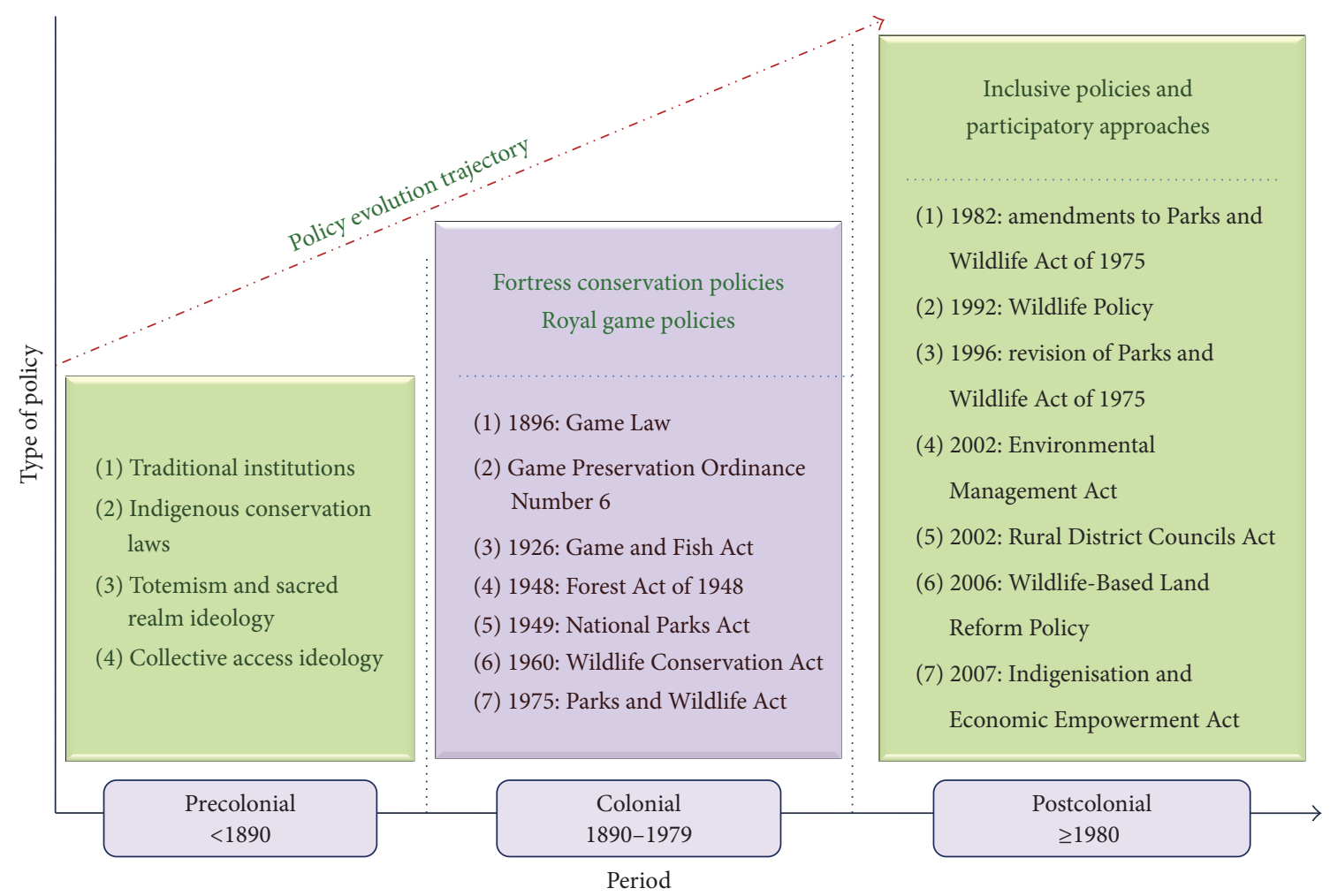

FIGURE 1: Framework showing the evolution (precolonial, colonial, and postcolonial period) of wildlife conservation and related policies in Zimbabwe. Sources: Murombedzi [7], St John et al. [50], Taylor [51], and Muboko and Murindagomo [52].

conservation areas devoid of human pressure and settlement, with highly restricted access to resources [66, 67]. Using controlled hunting areas, the colonial-era conservation policy enforced the royal game principle that further alienated indigenous people from the wildlife resource $[58,68]$. During this period, hunting was mainly the preserve of professional hunter-traders, adventurers, and explorers equipped with high precision rifles, for trade in trophies in Europe [7]. To some extent, there was some form of mass slaughter of animals by European settlers and hunters as they displayed a predatory attitude to African wildlife thus threatening the viability of these species due to overexploitation [69]. As a response to the depletion of the hitherto abundant wildlife species, there was the promulgation of the Game Law in 1896 aimed at regulating wildlife utilization through a license and permit system in order to reduce the growing export of game and prevention of commercialization of game $[68,70]$.

To augment the Game Law, the Game Preservation Ordinance "Number 6" was enacted in 1899. This ordinance had provisions to (1) specify and protect certain birds and animals, (2) stipulate times and seasons within which it was prohibited to kill, pursue, or shoot game without a license, and (3) classify some animals as royal game and restrict people from hunting or capturing them, for example, elephant (Loxodonta africana), giraffe (Giraffa camelopardalis), white rhino (Ceratotherium simum), kudu (Tragelaphus strepsiceros), and ostrich (Struthio camelus) [7, 68]. To further strengthen the philosophy of preservation of game and fish, the Game and Fish Act of 1929 was enacted. This act empowered governors to form game reserves and establish necessary management structures (game wardens and rangers) for the effective management of these reserves [7]. The alienation of local indigenous people resulted in more antagonism between the colonial settlers and the local people which resulted in more conflicts, environmental degradation, and habitat loss [71].

Owing to the need to conserve more land and wildlife species, further sanctuary areas were proclaimed and culminated in the present Parks and Wildlife Estate, from which the controlled hunting areas became safari areas [72]. Commercial wildlife utilization under a permit issued by government mainly for cropping animals for bush meat was made possible by the Wildlife Conservation Act of 1960 [58]. However, viability of cropping practices in game farms was low due to poor prices [73, 74]. Fortunately, in the mid-1960s, there was a boom in the international safari industry and the commercial activities of game ranches embraced safari hunting as the major form of wildlife exploitation [75, 76]. This led to the establishment of the Parks and Wildlife Act of 1975 that conferred privileges on owners and occupiers of land as custodians of wildlife and as such could utilize the resource freely. This act provided land holders with an economic incentive to reinforce the scientific, aesthetic, and moral justification for wildlife conservation $[77,78]$.

Postcolonial experienced rapid policy advances towards inclusiveness in natural resources management by ensuring that communities living with wildlife resources ought to benefit from managing such a resource. This resulted in amendments in 1982 on the Parks and Wildlife Act of 1975 to ensure 
that there were provisions ceding appropriate authority to Rural District Councils (RDCs) [79]. Appropriate Authority ensured that communities had de facto responsibility for wildlife, thus becoming beneficiaries of sound wildlife conservation and sustainable use through trophy hunting [51]. To date, trophy hunting activities in Zimbabwe are regulated through the revised Parks and Wildlife Act (Chapter 20:14) of 1996, the Wildlife Policy of 1992, and the Wildlife-Based Land Reform Policy of 2006 [52]. The Wildlife-Based Land Reform Policy included provisions that promoted the participation of indigenous Zimbabweans or local people in wildlife ranching or game farms as well as conservancies [80].

\subsection{Institutional Arrangements and Governance of Trophy} Hunting Zimbabwe. The Zimbabwe Parks and Wildlife Management Authority (ZPWMA) is the administrative agency and plays a regulatory role for all hunting activities in Zimbabwe. The governance of trophy hunting activities through ZPWMA is stipulated in trophy hunting in Zimbabwe and mainly occurs in three different systems or categories [58], that is, concessions under (1) state land (Parks and Wildlife Estates, Forestry Estates), (2) communal land (i.e., CAMPFIRE), and (3) private land (conservancies, game ranches, or farms). For the efficiency and proper management and monitoring of hunting activities in Zimbabwe, four mechanisms are in place: (a) system of protected areas (mostly safari areas), (b) CAMPFIRE and its coordinating arm (CAMPFIRE Association), (c) a financial facility (the Wildlife Conservation Fund), and (d) an administrative agency, ZPWMA [81].

3.3. Trophy Hunting Ethics and Policies in Zimbabwe. There are a set of ethical considerations that trophy hunters ought to adhere to during their hunting expeditions in Zimbabwe. Hunters are encouraged to ensure that they engage the principles of fair chase by all means possible. Fair chase principle entails the following: (a) the pursuit of a free ranging animal that still possesses the natural behavioural inclination to escape from the hunter and is fully free to do so, (b) that hunters avoid using artificial light source or a motorized mode of transport in an area that does not, by human design, concentrate animals for a specific purpose or at a specific time through provisioning or attraction (i.e., waterholes, salt, and mineral licks), (c) that no female animals with dependents or young ones shall be hunted [82]. Moreover, trophy hunters are not allowed to shoot and kill an animal within $400 \mathrm{~m}$ of the park boundary [58]. Besides these, Canopy [83] outlines some of the hunters' code of ethics as applied by ZPWMA: (1) do not shoot animals from a vehicle, aircraft, or boat, (2) avoid hunting animals at night and hunting "caged" or "canned" or captive bred animals, (3) avoid the use of spotting agents to locate animals, (4) avoid hunting animals in an inhumane way and leaving baits at the end of a hunt, (5) desist from luring animals with electronic calling devices, (6) avoid littering a hunting area, (7) desist from submitting falsified trophy measurements, (8) avoid mishandling and behaving irresponsibly with firearms, and (9) ensure hunters follow up on wounded animals.
3.4. Monitoring and Administration of Trophy Hunts in Zimbabwe. ZPWMA has the mandate of governing and monitoring all trophy hunting activities in the three land categories, that is, safari areas, CAMPFIRE areas, and private areas to safe guard its integrity and curb underhand dealings. As an authority, ZPWMA ensures that (1) professional standards and ethics are maintained, (2) quotas are set using sound ecological and sustainable use principles as well as quota approval, (3) only set trophies meeting the minimum sizes are exported out of the country, (4) there is a centralized trophy hunting monitoring system, and (5) all trophy hunting activities remain within bounds of the provisions under international conventions such as Convention on International Trade in Endangered Species of Wild Fauna and Flora (CITES) [58]. For these roles and many others that do not fall under trophy hunting, ZPWMA spends a substantial amount of money and resources each year in order to achieve its overarching mandate of conserving wildlife in Zimbabwe.

However, ZPWMA retains direct management control of hunting concessions in safari areas though much responsibility is shared with the safari operators. ZPWMA together with the safari operators helps in antipoaching activities and habitat protection of these conservation areas [84]. All the hunts are conducted in the presence of a professional hunter and trophy hunt monitor (i.e., a designated park ranger). Professional hunters are there to (a) supervise and oversee the hunting by the client, (b) ensure that hunting clients adhere to the laws and ethics regarding trophy hunting, and (c) record and keep a register of the hunting expedition of every hunting client [82]. Zimbabwe is able to maintain professional trophy hunting standards through a set of systems through ZPWMA, Safari Operators Association of Zimbabwe (SOAZ), and Zimbabwe Professional Hunters and Guide Association (ZPHGA). ZPWMA in association with SOAZ and ZPHGA conducts practical and written examinations for Learner Professional Hunters and later certifies one for Professional Hunters License after undertaking a two-year apprenticeship with a reputable licensed professional hunter [58].

These institutional and administrative systems enable the country to have an efficient monitoring and administration system for adaptive management purposes by ZPWMA with various stakeholders. To achieve this, there are a set of trophy hunting data forms for use in monitoring all hunting activities occurring in Parks and Wildlife Estate, communal areas, and private areas. Some of the forms are a legal requirement especially when processing CITES export permits for the trophies by the hunting clients. This is important given that Zimbabwe is a CITES signatory, thus making it mandatory to monitor species which are under CITES quota system. As a regulator, ZPWMA determines and ensures compliance regarding trophy hunting fees as mandated by provisions of the Parks and Wildlife Act (Chapter 20:14) of 1996, and Statutory Instrument 362 of 1990 provides for the ZPWMA (Tariff of fees) by-laws, 2014, on hunting trophy fees in concession areas. However, there are some concerns that the ZPWMA seems to be failing to fulfil its mandate. These concerns emanate from the idea that, as a regulatory authority, ZPWMA was probably 
not supposed to also operate as a safari operator or concessionaire as same institution cannot be a player and a regulator at the same time.

3.5. Forms of Trophy Hunting in Zimbabwe. Two main types of hunts occur in Zimbabwe; namely, (a) big game safaris can only be offered by operators who lease hunting concessions and are able to maintain elephant, lion, and buffalo populations and (b) plains game safaris are conducted by operators with concessions in ranches characterized by mixed wildlife and livestock farms that maintain good numbers of plains game. In each of these, hunting clients are able to choose their form of hunting as determined by the type of weapon during the hunt. The suitable and recommended firearms, the loads, and reloads vary with the target species as well as the hunting condition [85]. Although bow hunting used to be popular in Zimbabwe, this form of hunting has since declined as ZPWMA has strict requirements and is more expensive compared to rifle hunting. Nonetheless, bow hunting is considered as more environmentally friendly and quieter and causes less acoustic disturbance to wildlife than rifle hunting [86]. However, a new concept, darting safaris, that is being practiced in South Africa is yet to be practiced in Zimbabwe. Darting safaris are a form of hunting where the projectile (bullet or arrow) is replaced by a dart containing an immobilizing drug; thus the hunter would be able to take temporal possession of the immobilized animal [87]. This form of hunting is some form of green hunting and may go a long way in reducing loss of wildlife species as argued by many antihunting lobby groups [88]. However, darting safaris may somehow promote illegal harvesting by poaching syndicates through overdosing animals with immobilizing drugs as has been reported in rhinoceros poaching in South Africa [87].

3.6. Trophy Hunting in Zimbabwe's Parks and Wildlife Estate. The Parks and Wildlife Estates support a network of safari areas where most of the hunting occurs in Zimbabwe covering approximately $18,500 \mathrm{~km}^{2}$. Most of these areas occur in remote and dry regions of the country (Figure 2). These areas are leased to either individual or several hunting concessions through five-year lease arrangements with ZPWMA [89]. ZPWMA generates revenue from trophy hunting through (1) trophy fees, (2) administrative fees (punching and stamping fees), and (3) fixed quotas (a predetermined, fixed number of animals expected to be harvested from a population per hunting season $[90,91])$. Until recently, ZPWMA has been leasing all its concessions to private operators. As of 2012, ZPWMA has been conducting trophy hunting through its strategic business units for Matetsi Safari Area, concession units 2, 4, and 5 thus generating more income through trophy fees and daily rates from hunting clients. Daily rates refer to the combined fee charged to the trophy hunting clients by the concession holder meant to cater for the professional hunters own running costs such as leasing and maintaining concessions, running vehicles, and hunting lodges, as well as the profit margins $[58,81]$.
3.7. Trophy Hunting in CAMPFIRE Areas. There are several trophy hunting areas in Zimbabwe occurring mostly in remote and marginalized areas of the country, that is, CAMPFIRE areas [78]. In CAMPFIRE areas, trophy hunting has been observed to contribute enormously to the revenue accrued to Rural District Councils (RDCs) with appropriate authority (Figure 3(a)). In these areas, trophy hunting has been observed to contribute approximately $89.5 \%$ of the total revenue generated compared to about $2.3 \%$ by ecotourism [92], making trophy hunting the most viable land use option in these areas [23]. Most CAMPFIRE areas have lease holders who service these concessions for five or more years depending on the agreements which vary from district to districts [51]. These areas have personnel responsible for law enforcement, problem animal control, and wildlife monitoring as well as trophy hunts monitoring. The occurrence of partially stable wildlife populations and availability of good trophy species in these CAMPFIRE areas influences the long-term sustainability of trophy hunting. The population of one key species in trophy hunting in Zimbabwe, African elephant, has been observed to have steadily increased and stabilized during the period 1989-2014 (Figure 3(b)).

On the contrary, there has been a decline in the elephant populations in other regions of Africa, for example, central, eastern, and western Africa mostly due to overharvesting through illegal hunting activities, habitat loss, and droughts $[37,93,94]$. However, more effort needs to be put towards law enforcement as there has been a challenge of illegal hunting activities in some parts of Zimbabwe which has triggered much despondence and negative media framing $[84,95,96]$. A concerted effort towards monitoring animal populations, illegal off-takes, and trophy quality is critical for the sustainability of trophy hunting [97-99]. This information would provide essential scientific information required for adaptive management in lobbying and rebranding trophy hunting activities in these areas for the good of conservation [3]. In Zimbabwe, the 2015-2020 Elephant Management Plan (Box 1) specifically prescribes trophy hunting to manage elephant populations in a sustainable way (http://conservationaction.co.za/resources/reports/zimbabwe-national-elephantmanagement-plan-2015-2020/).

3.8. Trophy Hunting in Private Areas. Most private areas conducting trophy hunting in Zimbabwe are more specialized in plains game and have properties with high densities of wildlife species which attract trophy hunting clients [100]. In Zimbabwe, though there are several private conservation areas, the most prominent and key areas with high value trophy species include Bubiana Conservancy, Bubye River Conservancy, Chiredzi River Conservancy, Malilangwe Wildlife Reserve, and Save Valley Conservancy [101, 102] (Figure 2). These areas benefit from trophy hunting through the daily rates and other hidden costs. Nonetheless, there is very little information regarding returns from trophy hunting in these private areas though their combined contribution is almost $36 \%$ of the national trophy fees [81]. In some cases, the private areas also take advantage of trophy hunting and create side business such as bush meat sales [103] and biltong manufacturing $[104,105]$. Considering the lack of studies on trophy 


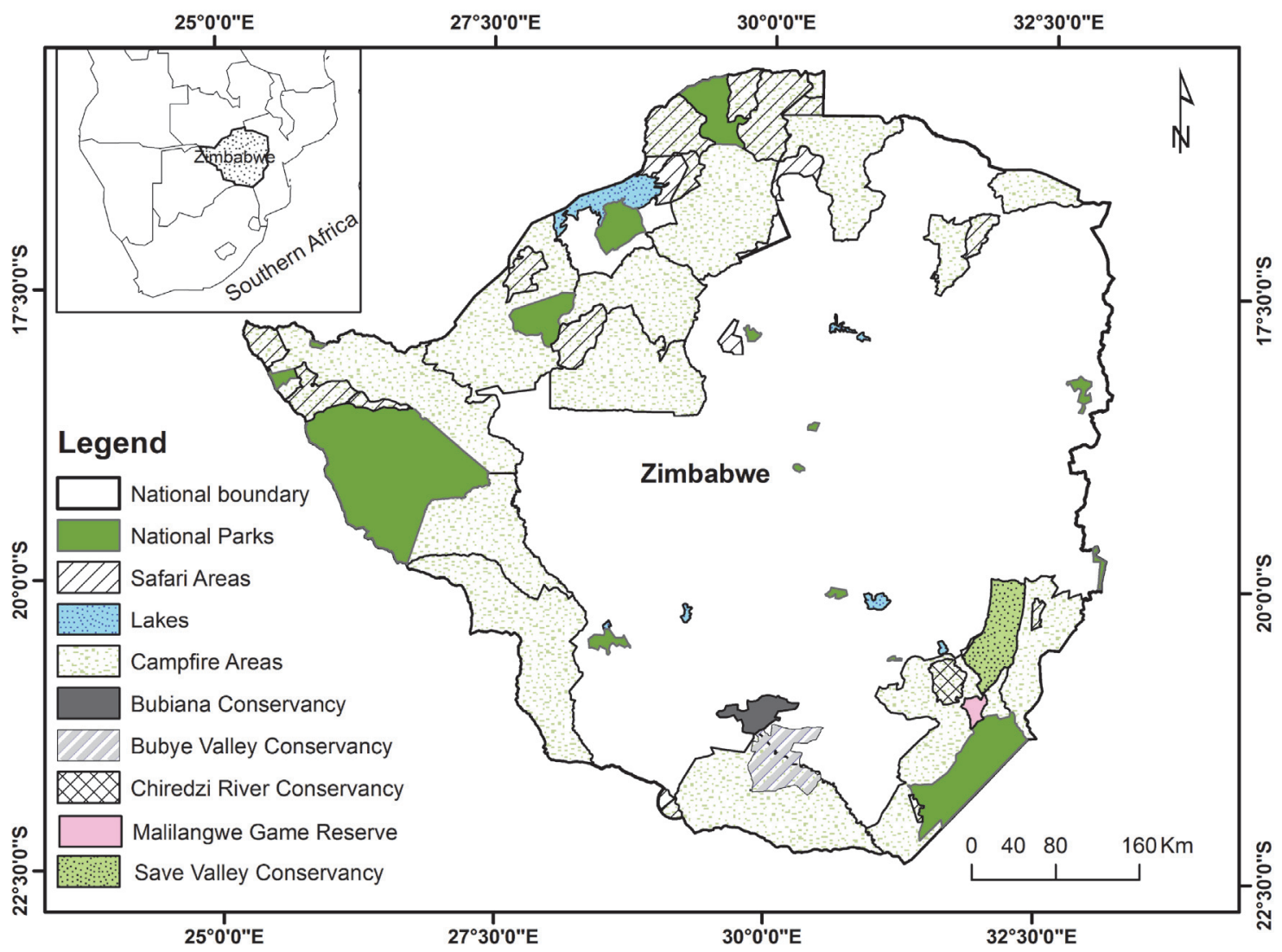

FIGURE 2: Map showing the key trophy hunting areas (safari areas, CAMPFIRE areas, and private conservancies) in relation to national parks in Zimbabwe. Source: data and information from the Surveyor General of Zimbabwe; WWF Programme Office in Harare, Cartography: V. K. Muposhi.

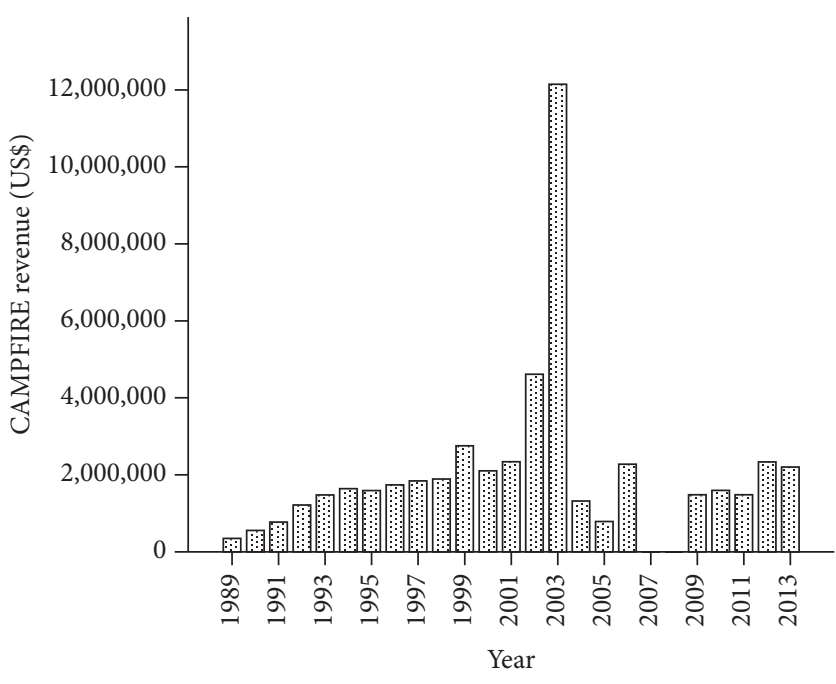

(a)

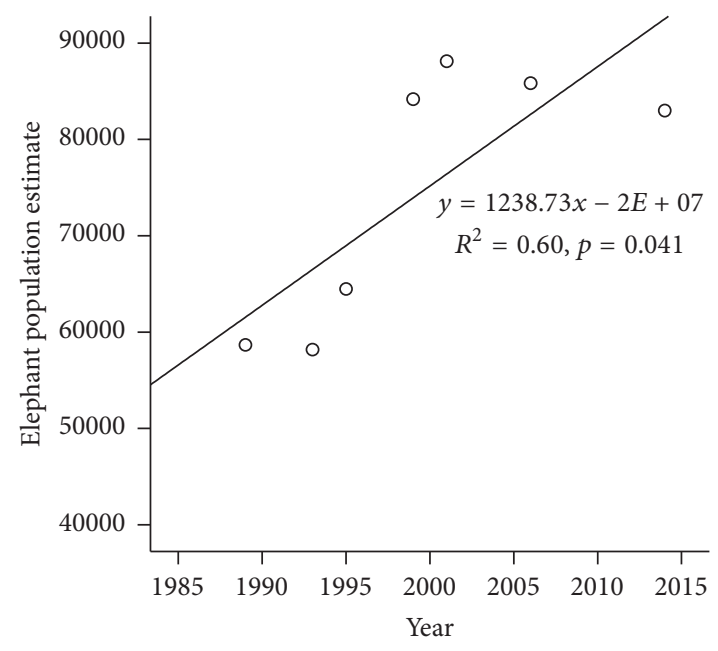

(b)

FIGURE 3: Long-term trends for (a) annual CAMPFIRE revenue for the period 1989-2013 and (b) elephant population as observed over the period 1989-2014 in Zimbabwe. Notes: there was no data for CAMPFIRE revenue for 2007 and 2008; data presented on elephant estimates were only for those years where national elephant aerial surveys were conducted. Data source: Gandiwa et al. [53], Gandiwa et al. [41], and http://www.greatelephantcensus.com/. 
hunting in Zimbabwe, it is difficult to ascertain the current state of private hunting areas after the land reform and distribution. Stakeholder consultations as well as other researchers show that there was loss of wildlife species through illegal hunting and habitat destruction; for example, more than 33\% of Save Valley Conservancy was fragmented due to the land redistribution program $[80,106]$. Other private conservation areas such as the Bubiana and Chiredzi River Valley conservancies were greatly affected, as these were almost totally fragmented and converted into small scale farms $[107,108]$.

\subsection{Significance of Trophy Hunting in Conservation Financing.} Wildlife conservation and protection of habitats is a costly undertaking as this land use option is constantly under threat due to the continued human population increase [109]. Trophy hunting has been for a long time considered an integral part of wildlife conservation and protection of habitats in Sub-Saharan Africa $[1,23]$. Due to the economic challenges facing African countries, particularly Zimbabwe [84], financial resources that may be channelled towards wildlife conservation may be low and as such both consumptive and nonconsumptive forms of wildlife utilization (i.e., trophy hunting and ecotourism) are beneficial [19, 110, 111]. Accordingly, trophy hunting can be considered as one of the payments for ecosystem services (PES) towards its payments for wildlife management initiatives from the trophy hunting revenue [30].

Wildlife management involves a lot of activities particularly law enforcement, fire management, and water supply over and above population monitoring activities [112]. These activities are therefore costly to undertake considering the extent of the protected areas network in Zimbabwe and the expected manpower levels required. As of 2014, ZPWMA had about 913 effective patrol men against a desired 1130 patrol men [113]. As such, ZPWMA tends to operate below optimal field staff levels for law enforcement due to low staffing levels as constrained by financial resources [113]. The optimum patrol effort per single field ranger is supposed to be one ranger per $20-24 \mathrm{~km}^{2}$ [84] which requires approximately about US $\$ 300-2000 / \mathrm{km}^{2}$ per annum for effective conservation of a protected area depending on the level of threats or disturbances $[114,115]$. To fund these operations requires large sums of money which may not be available through government support (i.e., through line ministry budgets from national funds) as is the case with some developing countries [116]. Trophy hunting is therefore a reliable source of revenue for park and protected area financing in most developing countries where little external support from donors and conservation agencies are supporting wildlife conservation.

Given that ZPWMA is now an autonomous authority, most of the generated revenue is channelled towards wildlife management and habitat protection as government does not have control over the funds it generates from trophy hunting as well as ecotourism other than taxes and some tourism levies. Before the land reform, Zimbabwe used to generate approximately US $\$ 16$ million annually from trophy hunting [110], from which a substantial amount of this was allocated for wildlife conservation and habitat protection. This figure has since declined due to the demise of some critical areas, that is, private game farms and conservancies that used to contribute annually and the current issues surrounding elephant and lion hunting from the international community. In communal lands (CAMPFIRE areas), a considerable proportion of the revenue generated through trophy hunting is reserved for wildlife conservation through law enforcement and problem animal control initiatives [51].

Annually, trophy hunting contributes approximately 90\% of the total revenue in CAMPFIRE areas [53]. A total of US $\$ 39$ million was generated by CAMPFIRE between 1994 and 2012, of which US $\$ 22$ million was allocated to communities and used for resource management (22\%), household benefits (26\%), and community projects (52\%) [53]. It has been observed that, in CAMPFIRE areas, trophy hunting does provide incentives for local communities to conserve wildlife species and their associated habitats particularly [111, 117]. Nonetheless, CAMPFIRE has also been affected by other factors that are more related to governance and devolution issues [118]. Despite the increase in poaching, unscrupulous hunting safari operators, continued human-wildlife conflicts, reduced flow of financial benefits to producer communities, and economic decline Zimbabwe has been experiencing after the year 2000, CAMPFIRE still remains a resilient programme that incentivizes wildlife conservation [119]. Arguably, without these incentives (i.e., loss of revenue through trophy banning), most of the wildlife habitats in these vast areas would be converted into other land use options (e.g., livestock rearing and land clearing for agriculture) and most of the wildlife illegally hunted as a survival strategy by the marginalized and vulnerable communities $[31,120,121]$.

3.10. Emerging Issues in Trophy Hunting Industry and Future Interventions. Based on the opinions from interviewed experts, five emerging issues that may affect the trophy hunting industry were identified and these were all commensurate with the literature reviewed. The identified critical emerging issues arising from wildlife conservation that may affect the sustainability of trophy hunting as a practice at national or local level include (1) continuous population decline of key species in their usual range [37, 122, 123], (2) illegal hunting $[38,84,124]$, habitat loss, and fragmentation [40, 125], (3) human population growth and encroachment into wildlife habitats $[126,127],(4)$ redundant quota setting approaches, wildlife-based land reform policies [80, 106, 128, 129], and (5) poor conservation financing and reduced law enforcement capacity $[84,96]$. In Zimbabwe, at local or national scale, these issues occur in three land tenure systems in various forms and magnitude and do cascade to regional and global scales (Figure 4).

Illegal hunting through poisoning has been a serious challenge in Zimbabwe [38, 95] as it has resulted in loss of other species, for example, vultures [130, 131]. However, illegal hunting benefits accrue to only a few people whereas those for sport hunting are broad-based benefits that contribute towards local community development, conservation financing, and the national economy at large. On the other hand, hunting indirectly in the park triggers source and sink 


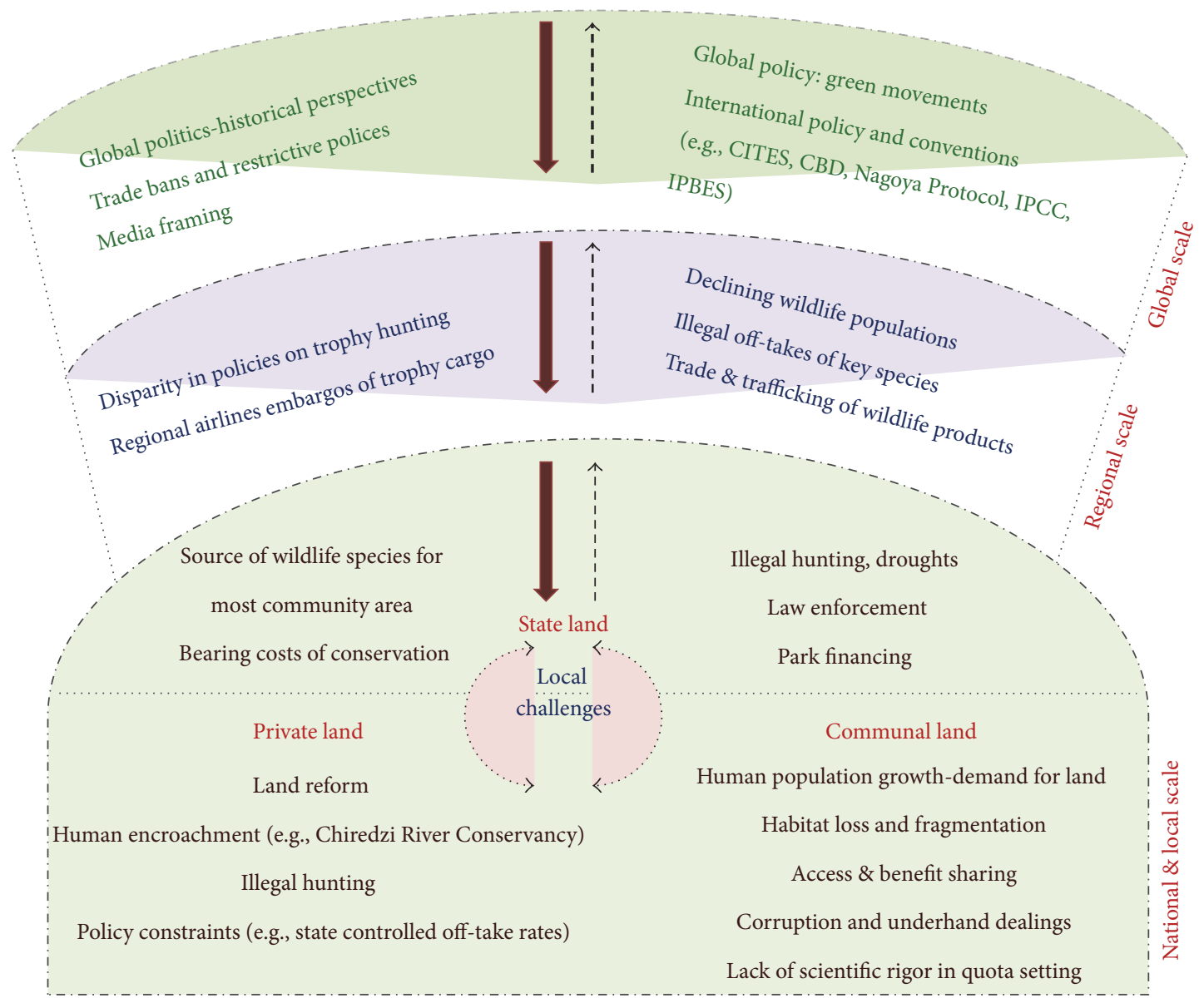

FIGURE 4: Representation of scales (national and local, regional and global) influencing trophy hunting as a conservation tool in Zimbabwe. Local scales are influenced by the three land tenure (i.e., state, community, and private land) systems in Zimbabwe. Existing feedbacks are indicated by arrows where solid dark arrows show strong influences (top down, global to local level) and broken lines show weak influences (bottom up, local to global level). Adapted from Giller et al. [54].

dynamics of trophy individuals between the park and hunting area and adverse effects on wildlife populations in protected areas [132]. Incidences where trophy hunting is thought to have been conducted along the boundaries of protected areas have been reported for lions and other carnivores in western Zimbabwe [133] and northern Zimbabwe [134]. We argue that there may be a lack of proper monitoring systems and implementation of some policies in Zimbabwe that prohibits trophy hunting within the stipulated $400 \mathrm{~m}$ of the park boundary. To address this challenge, there is need to (i) revisit the buffer zone concept surrounding protected areas and evaluate its applicability and usefulness in conservation efforts in line with the land redistribution policies and (ii) develop and implement more rigorous policies near boundaries and within buffer zones to reduce encroachment into protected areas.

Though the quota system used in trophy hunting is based on ecological theory [16], there are some cases where the quota setting process does lack the scientific rigor due to absence of empirical data requisite for such important decision making processes [117]. Most of the experts viewed the quota setting process in Zimbabwe as overly relaying on opinions of stakeholders and not based on the monitoring data on population sizes thus compromising the sustainability of the process. Similarly there have been reports on the decline in trophy size of hunted species in some cases in Zimbabwe [97] as has also been the case with other regional countries, that is, South Africa $[98,99,135]$, western Tanzania [136], and Zambia [137]. It is somehow believed that there seems to be a lack of implementation of age based harvesting strategies as required by the Zimbabwean policies on trophy hunting [58]. Nonetheless, we suggest that the use of the quota system may be problematic as has also been observed in global fish catch declines in aquatic ecosystems where the approach has been widely used [138]. Due to these challenges, we question the sustainability of quota system used for harvesting regimes used in trophy hunting in Zimbabwe. The fixed quota system is unfortunately believed to cause catastrophic overharvesting of wildlife species and can be a very risky harvesting strategy [90]. The quota setting process in Zimbabwe could be strengthened by ensuring that (1) reliable ecological data (e.g., animal population estimates) is used for all the decisions for allocating quota and not based on past experiences or other motivations, (2) decisions on quotas are based on the estimates of old or mature trophy individuals in a population 
instead of using the entire population estimate, and (3) the fixed quota policy is repealed and replaced with a flexible and sustainable approach that does not force safari operators to hunt nontrophy individuals as a way of satisfying the fixed quota requirements.

At regional level, that is, Sub-Saharan Africa, the effectiveness of trophy hunting as a tool that enhances wildlife conservation incentives is hampered by the lack of adequate political, legal, and governance instruments $[12,110]$. We consider the regional disparity in conservation policy related to hunting to be attributed to lack of sufficient scientific data in decision and support tools. In wildlife conservation, weak policy instruments, governance, and control systems may result in a decline in wildlife species due to despondence by local communities which triggers to some extent illegal activities [139].

On the other hand, global and regional issues that influence trophy hunting are mostly concerned about global politics, policy issues $[140,141]$, and illegal trade and trafficking of wildlife products [142-144]. Some key species especially elephant and lions are governed internationally through a quota system through CITES and tend to reduce impact on these species. However, over the years, international pressures to ban trophy hunting have been mounting to worrying levels [49] and have influenced policies of many countries, for example, Botswana, Kenya, United States of America, and Zambia. These policy changes are worrisome as they may compromise the suitability of wildlife conservation as a suitable land use option especially by local communities at local level. Recently, the media framing of trophy hunting has been negative and emotive following the killing of "Cecil" the lion in Zimbabwe [35]. Morality and ethical issues are also becoming more poised to influence trophy hunting as a practice given the hype and intensity of debates on social media platforms at global level $[43,145]$. Several nonhunting pressure groups have since intensified the need to ban trophy hunting completely as it is viewed as unethical and a practice that may push key species to extinction if not stopped. However, such international pronouncements may seriously affect wildlife conservation at local level and may lead to wildlife declines through illegal hunting and habitat loss $[49,110]$.

3.11. Options and Implications for Conservation. Regionally, conservationists have modified a program that was meant to finance rhinoceros ear-notching, microchipping, and tissue collection to create a new concept that embraces the principle of trophy hunting, that is, darting safaris [87] branded as the "green bullet concept" [146]. There exist such opportunities for the trophy hunting industry in Zimbabwe particularly in well-developed private concessions. However, this concept requires strict policies and guidelines as it is prone to abuse by corrupt and unethical hunters as observed in South Africa [87]. Although darting safaris may be considered as an alternative to lethal trophy hunting practices for key wildlife species [146], the practice of repeated chemical immobilizers on the same animal by scrupulous "hunters" may result in long-term physiological impacts on the targeted species [147, 148], and as such its applicability needs to be assessed over time for sustainability.
However, there is an opportunity cost associated with conserving wildlife and their habitats over other land use options (e.g., livestock production and farming) and suitable livelihoods forms. We propose the need for a regional and international wildlife conservation credit system similar to the carbon credit applied under climate change $[149,150]$. The wildlife conservation credit could be considered as part of the payments for ecosystem services $[30,151]$, for those who decide to avoid trophy hunting and support nonconsumptive forms of wildlife utilization. Nonetheless, ecotourism on its own may not be enough to support the conservation as has been observed in some underperforming protected areas [116]. Currently, conservation financing in protected areas is done through revenue from ecotourism activities, trophy hunting as well as live sales of wildlife species. There is no financial support from government "treasury" as in other countries thus making ecotourism and trophy hunting the key sources of revenue for conservation in Zimbabwe. We however argue that, in cases where diversification of park financing options exists, conservation financing may not necessarily need to depend on revenue from trophy hunting. Examples of such diversification options may include public private partnerships (e.g., Umfurudzi Park, Pioneer Africa Corporation [152]) and international support from conservation societies (e.g., Gonarezhou National Park, Frankfurt Zoological Society [84]).

Similarly, Di Minin et al. [110] suggest the use of net conservation benefits which involves (a) imposing mandatory levies on safari operators to generate funds that are further invested directly into the wildlife conservation trust funds for conservation and management and (b) use of eco-labelling and certification schemes adopted for trophies originating from areas that contribute to broader biodiversity conservation and respect animal welfare concerns. More holistic approaches that will promote wildlife and habitat conservation as well as empowering the local people in a sustainable manner ought to be sought for in order to promote biodiversity conservation. Here we present a conceptual framework showing the significance of trophy hunting to conservation and rural development as well as alternative forms of revenue generation through an alternative form and natural resources product diversification (Figure 5).

There is need to strengthen the biological sustainability and adaptive management involving planning, monitoring, and reporting of trophy hunting related information in private, community, and state land. In light of this view, there is need for mandatory (1) capacity building and population viability analysis to ensure that trophy hunting off-takes will not affect population growth of target species, (2) detailed population management plans submitted to the management authority before extension of permits, and (3) scientific biosampling of hunted animals, for molecular genetics, teeth for age analysis, full morphometrics, and disease screening [46]. Some of the emerging local issues could be addressed by ensuring that accountable and efficient governance systems are enacted and implemented as well as introducing the independent certification of hunting operators $[12,153]$. Accountability from stakeholders would entail (a) full disclosure to the public of all data collected and levied amounts (i.e., trophy 


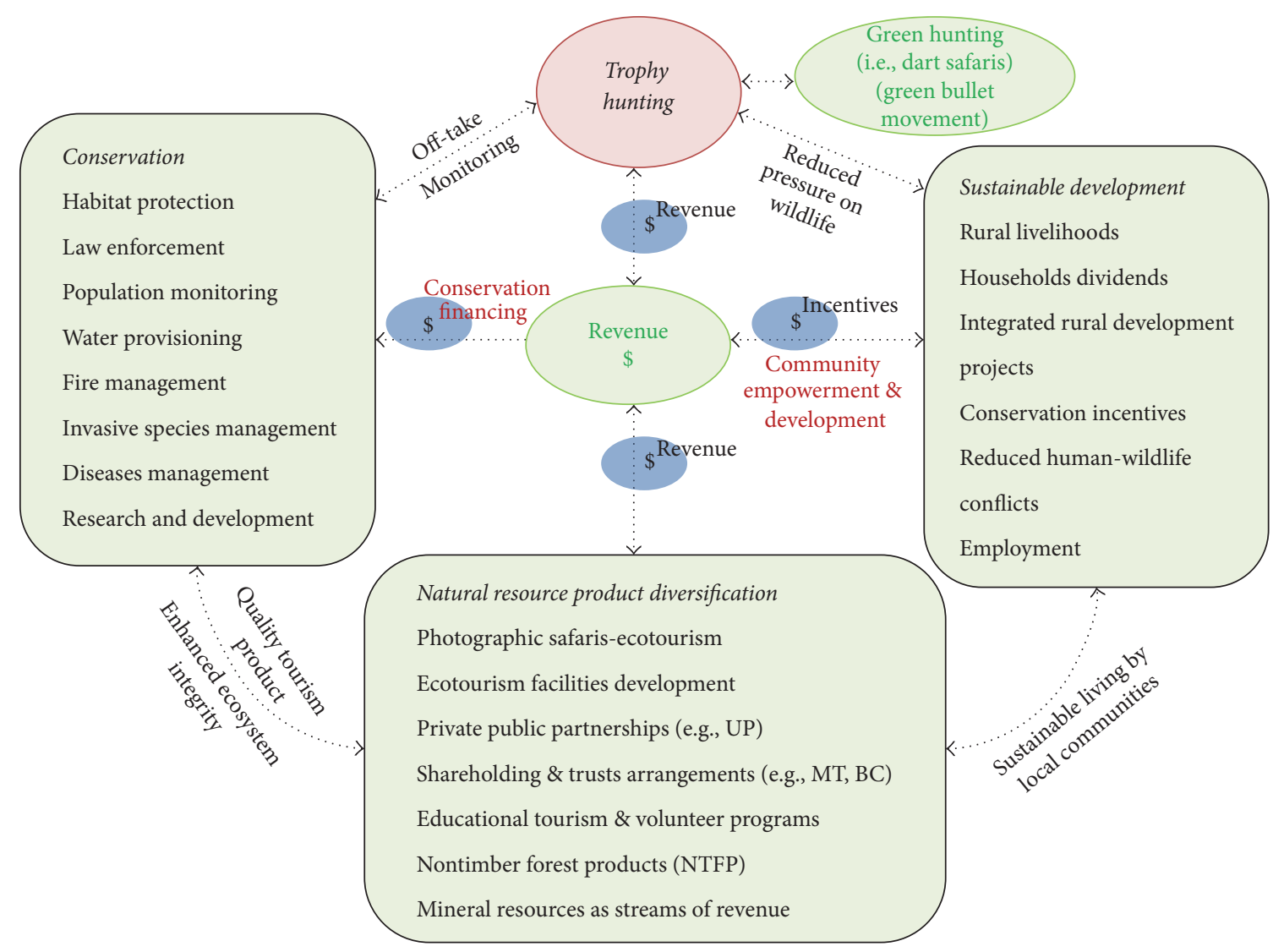

FIGURE 5: Conceptual framework showing the significance of trophy hunting to conservation and rural development as well as alternative forms of revenue generation through natural resources product diversification. Notes: UP denotes Umfurudzi Safari Area, MT: Malilangwe Trust, and BC: Bubiana Conservancy, in Zimbabwe.

fees, daily rates), although personal details of proponents may be held by government legislators, (b) constituting independent observers or monitors, placed randomly and without forewarning on safari hunts as they occur, and (c) imposing stiffer penalties (including withdrawal of operator's license) on perpetrators found engaging in unethical hunting activities and illegal practices [110].

\section{Conclusion}

In this paper, we explored the Zimbabwean perspective of trophy hunting by examining the following: (1) evolution of trophy hunting and related policies, (2) trophy hunting administration and governance, (3) significance of trophy hunting in conservation financing, and (4) emerging challenges in trophy hunting industry and future interventions for Zimbabwe. We found that the policies related to trophy hunting and conservation in Zimbabwe constantly evolved in response to local and international needs. Similarly, the governance of trophy hunting has also evolved with time due to local, regional, and international pressure though there is still need to strengthen associated institutional frameworks to retain the integrity of the industry and its sustainability. There is convincing evidence that trophy hunting plays a crucial role in creating incentives for conservation for especially rural communities sharing space with wildlife as well as financing wildlife conservation activities ranging from law enforcement and habitat protection for community, private, and state run conservation areas in Zimbabwe. We found that trophy hunting in Zimbabwe seems to be affected by weak administrative and governance systems and lack of capacity and financing for planning, monitoring, and reporting for adaptive management. We conclude that trophy hunting still plays an important role in wildlife conservation in developing economies where conservation financing is limited due to fiscal constraints. As such, we recommend (i) adapting some innovative measures in harvesting strategies aimed at maintaining viable wildlife populations (i.e., adoption of adaptive harvesting management strategies), (ii) rebranding of trophy hunting image and portrayal to reflect its contribution to conservation and rural community development, (iii) the need to promote net conservation benefits for positive conservation efforts, and (iv) promoting the use of wildlife conservation credits for the opportunity costs associated with reducing offtake levels through trophy hunting.

\section{Competing Interests}

The authors declare no conflict of interests. 


\section{Acknowledgments}

This work was supported by Chinhoyi University of Technology, Grant no. PG4122. The authors are grateful to Mr. Clive Stockil, Dr. Bruce Clegg, Mr. Charles Jonga, Mr. George Pangeti, Dr. Hillary Madzikanda, Mr. T. Gotosa, Mr. Tinaapi H. Madiri, Mr. Exeverino Chinoitezvi, and Mr. Jan Stander for the insightful discussions. They extend their thanks to Mellinda Rushinga, Admire Chanyandura, and Augustine Jeke for their help in data collection. They are also grateful to Chido Meda for the assistance in manuscript preparation.

\section{References}

[1] N. Leader-Williams, "Conservation and hunting: friends or foes," in Recreational Hunting, Conservation, and Rural Livelihoods, B. Dickson, J. Hutton, and B. Adams, Eds., pp. 9-24, John Wiley \& Sons, London, UK, 2009.

[2] T. Ingold, D. Riches, and J. Woodburn, Hunters and Gatherers: Volume 1: History, Evolution and Social Change; Volume 2: Property, Power and Ideology, Berg Publishers, 1991.

[3] G. R. Damm, "Branding hunting," African Indaba e-Newsletter, vol. 13, pp. 1-3, 2015.

[4] M. J. Westgate, D. A. Driscoll, and D. B. Lindenmayer, "Can the intermediate disturbance hypothesis and information on species traits predict anuran responses to fire?” Oikos, vol. 121, no. 10, pp. 1516-1524, 2012.

[5] P. S. Martin, "Africa and pleistocene overkill," Nature, vol. 212, no. 5060, pp. 339-342, 1966.

[6] E. Gandiwa, "Top-down and bottom-up control of large herbivore populations: a review of natural and human-induced influences," Tropical Conservation Science, vol. 6, no. 4, pp. 493505, 2013.

[7] J. Murombedzi, Pre-Colonial and Colonial Conservation Practices in Southern Africa and their Legacy Today, World Conservation Union (IUCN), Washington, DC, USA, 2003.

[8] W. M. Adams, Against Extinction: The Story of Conservation, Earthscan, London, UK, 2013.

[9] S. P. Mahoney and J. J. Jackson III, "Enshrining hunting as a foundation for conservation-the North American model," International Journal of Environmental Studies, vol. 70, no. 3, pp. 448-459, 2013.

[10] S. P. Mahoney, "Recreational hunting and sustainable wildlife use in North America," in Recreational Hunting, Conservation and Rural Livelihoods: Science and Practice, pp. 266-281, Blackwell Publishing, 2009.

[11] E. J. Milner-Gulland, N. Bunnefeld, and G. Proaktor, "The science of sustainable hunting," in Recreational Hunting, Conservation and Rural Livelihoods, B. Dickson, J. Hutton, and B. Adams, Eds., pp. 75-93, John Wiley \& Sons, Oxford, UK, 2009.

[12] P. A. Lindsey, L. G. Frank, R. Alexander, A. Mathieson, and S. S. Romañach, "Trophy hunting and conservation in africa: problems and one potential solution," Conservation Biology, vol. 21, no. 3, pp. 880-883, 2007.

[13] W. I. Morrill, The Tourist Safari Hunter's Role in Conservation, Safari Club International, Herndon, Va, USA, 1993.

[14] H. S. Cooley, R. B. Wielgus, G. M. Koehler, H. S. Robinson, and B. T. Maletzke, "Does hunting regulate cougar populations? A test of the compensatory mortality hypothesis," Ecology, vol. 90, no. 10, pp. 2913-2921, 2009.
[15] J. A. Jenks, W. P. Smith, and C. S. DePerno, "Maximum sustained yield harvest versus trophy management," Journal of Wildlife Management, vol. 66, no. 2, pp. 528-535, 2002.

[16] W. J. Sutherland, "Sustainable exploitation: a review of principles and methods," Wildlife Biology, vol. 7, no. 3, pp. 131-140, 2001.

[17] K. Whitman, A. M. Starfield, H. S. Quadling, and C. Packer, "Sustainable trophy hunting of African lions," Nature, vol. 428, no. 6979, pp. 175-178, 2004.

[18] R. Buckley and A. Mossaz, "Hunting tourism and animal conservation," Animal Conservation, vol. 18, no. 2, pp. 133-135, 2015.

[19] G. R. Damm, "Recreational trophy hunting: 'what do we know and what should we do?," in Best Practices in Sustainable Hunting-A Guide to Best Practices from around the World, R. D. Baldus, G. R. Damm, and K. Wollscheid, Eds., pp. 5-11, International Council for Game and Wildlife Conservation, 2008.

[20] V. K. Muposhi, E. Gandiwa, S. M. Makuza, and P. Bartels, "Trophy hunting and perceived risk in closed ecosystems: flight behaviour of three gregarious African ungulates in a semi-arid tropical savanna," Austral Ecology, vol. 41, no. 7, pp. 809-818, 2016.

[21] U. Grimm, “Trophy hunting for endangered species," in Best Practices in Sustainable Hunting-A Guide to Best Practices from Around the World, R. D. Baldus, G. R. Damm, and K. Wollscheid, Eds., pp. 17-19, International Concil for Game \& Wildlife Conservation, Budakeszi, Hungary, 2008.

[22] W. J. Ripple, T. M. Newsome, C. Wolf et al., "Collapse of the World's largest herbivores," Science Advances, vol. 1, no. 4, Article ID e1400103, 2015.

[23] P. A. Lindsey, R. Alexander, L. G. Frank, A. Mathieson, and S. S. Romañach, "Potential of trophy hunting to create incentives for wildlife conservation in Africa where alternative wildlife-based land uses may not be viable," Animal Conservation, vol. 9, no. 3, pp. 283-291, 2006.

[24] R. Naidoo, L. C. Weaver, R. W. Diggle, G. Matongo, G. StuartHill, and C. Thouless, "Complementary benefits of tourism and hunting to communal conservancies in Namibia," Conservation Biology, vol. 30, no. 3, pp. 628-638, 2016.

[25] K. I. MacDonald, "Global hunting grounds: power, scale and ecology in the negotiation of conservation," Cultural Geographies, vol. 12, no. 3, pp. 259-291, 2005.

[26] A. Ochieng, W. M. Ahebwa, and I. J. Visseren-Hamakers, "The re-introduction of sport hunting in Uganda examined," in Institutional Arrangements for Conservation, Development and Tourism in Eastern and Southern Africa, pp. 139-155, Springer, Berlin, Germany, 2015.

[27] A. M. Rosser, N. Tareen, and N. Leader-Williams, “The precautionary principle, uncertainty and trophy hunting: a review of the torghar population of central Asian markhor Capra falconeri," in Biodiversity and the Precautionary Principle: Risk, Uncertainty in Conservation and Sustainable Use, R. Cooney and B. Dickson, Eds., pp. 55-72, Earthscan, London, UK, 2005.

[28] N. Leader-Williams, S. Milledge, K. Adcock et al., “Trophy hunting of black rhino Diceros bicornis: proposals to ensure its future sustainability," Journal of International Wildlife Law \& Policy, vol. 8, no. 1, pp. 1-11, 2005.

[29] E. Gandiwa, I. M. A. Heitkönig, A. M. Lokhorst, H. H. T. Prins, and C. Leeuwis, "CAMPFIRE and human-wildlife conflicts in local communities bordering northern Gonarezhou National Park, Zimbabwe," Ecology and Society, vol. 18, no. 4, article 7, 2013. 
[30] P. G. H. Frost and I. Bond, "The CAMPFIRE programme in Zimbabwe: payments for wildlife services," Ecological Economics, vol. 65, no. 4, pp. 776-787, 2008.

[31] P. A. Lindsey, P. A. Roulet, and S. S. Romañach, "Economic and conservation significance of the trophy hunting industry in subSaharan Africa," Biological Conservation, vol. 134, no. 4, pp. 455469, 2007.

[32] B. Child, "Making wildlife pay: converting wildlife's comparative advantage into real incentives for having wildlife in african savannas, case studies from Zimbabwe and Zambia," in Wildlife Conservation by Sustainable Use, H. H. T. Prins, J. G. Grootenhuis, and T. T. Dolan, Eds., pp. 335-387, Kluwer Academic, Boston, Mass, USA, 2000.

[33] R. B. Martin, Communal areas management programme for indigenous resources (campfire), Revised version, Campfire working document no. 1/86, Branch of terrestrial ecology, department of national parks and wild life management, Harare, Zimbabwe, 1986.

[34] W. Wolmer, J. Chaumba, and I. Scoones, "Wildlife management and land reform in southeastern Zimbabwe: a compatible pairing or a contradiction in terms?" Geoforum, vol. 35, no. 1, pp. 87-98, 2004.

[35] P. A. Lindsey, G. A. Balme, P. J. Funston, P. H. Henschel, and L. T. B. Hunter, "Life after Cecil: channelling global outrage into funding for conservation in Africa," Conservation Letters, vol. 9, no. 4, pp. 296-301, 2016.

[36] A. J. Loveridge, J. C. Reynolds, and E. J. Milner-Gulland, "Is sport hunting part of conservation?" in Key Topics in Conservation, D. W. Macdonald and K. Service, Eds., pp. 224-240, Blackwell, Oxford, UK, 2006.

[37] I. D. Craigie, J. E. M. Baillie, A. Balmford et al., "Large mammal population declines in Africa's protected areas," Biological Conservation, vol. 143, no. 9, pp. 2221-2228, 2010.

[38] N. Muboko, V. Muposhi, T. Tarakini, E. Gandiwa, S. Vengesayi, and E. Makuwe, "Cyanide poisoning and African elephant mortality in Hwange National Park, Zimbabwe: a preliminary assessment," Pachyderm, vol. 55, pp. 92-94, 2014.

[39] C. Kiffner, C. Wenner, A. Laviolet, K. Yeh, and J. Kioko, "From savannah to farmland: effects of land-use on mammal communities in the Tarangire-Manyara ecosystem, Tanzania," African Journal of Ecology, vol. 53, no. 2, pp. 156-166, 2015.

[40] K. H. Fitzgerald, "The silent killer: habitat loss and the role of African protected areas to conserve biodiversity," in Protecting the Wild, pp. 170-188, Springer, 2015.

[41] E. Gandiwa, S. Sprangers, S. van Bommel, I. M. A. Heitkönig, C. Leeuwis, and H. H. T. Prins, "Spill-over effect in media framing: representations of wildlife conservation in Zimbabwean and international media, 1989-2010," Journal for Nature Conservation, vol. 22, no. 5, pp. 413-423, 2014.

[42] C. A. E. Sorensen, Trophy Hunting in the Us Media: A Macroand Micro-Level Frame Analysis, Central European University, Budapest, Hungary, 2015.

[43] D. W. Macdonald, K. S. Jacobsen, D. Burnham, P. J. Johnson, and A. J. Loveridge, "Cecil: a moment or a movement? Analysis of media coverage of the death of a lion, Panthera leo," Animals, vol. 6, article 26, 2016.

[44] R. F. Rentería-Valencia, "Ethics, hunting tales, and the multispecies debate: the entextualization of nonhuman narratives," Visual Anthropology Review, vol. 31, no. 1, pp. 94-103, 2015.

[45] M. Gross, "Can we change our predatory ways?" Current Biology, vol. 25, no. 20, pp. R965-R967, 2015.
[46] E. Di Minin, N. Leader-Williams, and C. J. Bradshaw, "Banning trophy hunting will exacerbate biodiversity loss," Trends in Ecology \& Evolution, vol. 31, pp. 99-102, 2016.

[47] F. Fleischman and D. Briske, "Professional ecological knowledge: an unrecognized knowledge domain within natural resource management," Ecology and Society, vol. 21, no. 1, p. 32, 2016.

[48] Friends-of-Animals, Mail, via certified: Notice of petition for rule making notice, Washington, DC, USA, 2015.

[49] K. Conrad, “Trade bans: a perfect storm for poaching?” Tropical Conservation Science, vol. 5, no. 3, pp. 245-254, 2012.

[50] F. A. St John, A. M. Keane, G. Edwards-Jones, L. Jones, R. W. Yarnell, and J. P. Jones, "Identifying indicators of illegal behaviour: carnivore killing in human-managed landscapes," Proceedings of the Royal Society of London B: Biological, vol. 279, no. 1729, 2012.

[51] R. Taylor, "The performance of campfire in Zimbabwe: 19892006," in Evolution and Innovation in Wildife Conservation: Parks and Game Ranches to Transfrontier Conservation Areas, $\mathrm{H}$. Suich, B. Child, and A. Spenceley, Eds., pp. 202-222, Earthscan, London, UK, 2012.

[52] N. Muboko and F. Murindagomo, "Wildlife control, access and utilisation: lessons from legislation, policy evolution and implementation in Zimbabwe," Journal for Nature Conservation, vol. 22, no. 3, pp. 206-211, 2014.

[53] E. Gandiwa, C. Jonga, and O. Mufute, Proceedings of the CAMPFIRE stakeholders' workshop: Towards the development of a new Elephant Management Plan and Policy, Harare, Zimbabwe, 17-18 November 2014.

[54] K. E. Giller, C. Leeuwis, J. A. Andersson et al., "Competing claims on natural resources: what role for science?" Ecology and Society, vol. 13, no. 2, article no. 34, 2008.

[55] S. Atkins, S. Lewin, H. Smith, M. Engel, A. Fretheim, and J. Volmink, "Conducting a meta-ethnography of qualitative literature: lessons learnt," BMC Medical Research Methodology, vol. 8, article 21, 2008.

[56] T. Stankowich, "Ungulate flight responses to human disturbance: a review and meta-analysis," Biological Conservation, vol. 141, no. 9, pp. 2159-2173, 2008.

[57] K. M. Dunham, C. S. Mackie, G. Nyaguse, and C. Zhuwau, Aerial Survey of Elephants and Other Large Herbivores in NorthWest Matebeleland (Zimbabwe): 2014, Great Elephant Census Project, Harare, Zimbabwe, 2015.

[58] R. Barnett and C. Patterson, Sport Hunting in the Southern African Development Community (Sadc) Region: An Overview, TRAFFIC East/Southern Africa, Johannesburg, South Africa, 2005.

[59] A. Chigwenya and D. Manatsa, "The history of natural resource management in Zimbabwe: a chronicle of how sustainable resource management has remained an elusive concept," Journal of Sustainable Development in Africa, vol. 9, no. 2, pp. 102-115, 2007.

[60] J. Z. Z. Matowanyika, Indigenous resource management and sustainability in rural Zimbabwe: an exploration of practices and concepts in common lands [Ph.D. thesis], University of Waterloo, Waterloo, Canada, 1991.

[61] A. Newsham, Participation: Processes, Problematic and Campfire. A Centre of African Studies Occasional Paper, University of Edinburgh, 2002.

[62] V. C. Kwashirai, Environmental History of Africa, Encyclopedia of Life Support Systems, 2012. 
[63] H. Siurua, "Nature above people: rolston and 'fortress' conservation in the south," Ethics \& the Environment, vol. 11, no. 1, pp. 71-96, 2006.

[64] K. B. Ghimire and M. P. Pimbert, Social Change and Conservation: Environmental Politics and Impacts of National Parks and Protected Areas, Earthscan, London, UK, 1997.

[65] B. Büscher and T. Dietz, "Conjunctions of governance: the state and the conservation-development nexus in Southern Africa," Journal of Transdisciplinary Environmental Studies, vol. 4, pp. 1$15,2005$.

[66] W. Adams, "Nature and the colonial mind," in Decolonizing Nature: Strategies for Conservation in a Post-Colonial Era, W. Adams and M. Mulligan, Eds., pp. 16-50, Earthscan, London, UK, 2003.

[67] S. Jones, "A political ecology of wildlife conservation in Africa," Review of African Political Economy, vol. 33, no. 109, pp. 483495, 2006.

[68] G. F. T. Child, "Problems and progress in nature conservation in rhodesia," Koedoe, vol. 20, pp. 116-137, 1977.

[69] R. Mutwira, "Southern Rhodesian wildlife policy (1890-1953): a question of condoning game slaughter?" Journal of Southern African Studies, vol. 15, no. 2, pp. 250-262, 1989.

[70] T. Masona, Colonial game policy: a study of the origin and administration of game policy in southern rhodesia-1890-1945 [Ph.D. dissertation], University of Zimbabwe, Harare, Zimbabwe, 1987.

[71] D. Hulme and M. Murphree, African Wildlife and Livelihoods: The Promise and Performance of Community Conservation, James Currey, Oxford, UK, 2001.

[72] J. M. MacKenzie, The Empire of Nature: Hunting, Conservation and British Imperialism, Manchester University Press, Manchester, UK, 1988.

[73] B. A. Child, J. Musengezi, G. D. Parent, and G. F. Child, “The economics and institutional economics of wildlife on private land in Africa," Pastoralism, vol. 2, pp. 1-32, 2012.

[74] I. Bond, "The economics of wildife and landuse in Zimbabwe: an examination of current knowledge and issues," in WWF Multiplespecies Animal Productions Systems Project, Project Paper no. 36, 1993.

[75] B. A. Child, The Role of Wildlife Utilization in the Sustainable Economic Development of Semi-Arid Rangelands in Zimbabwe, Oxford University, Oxford, UK, 1988.

[76] D. Jansen, I. Bond, and B. Child, "Cattle, wildlife, both or neither. Results of a financial and economic survey of commercial ranches in Southern Zimbabwe," Project Paper 27, WWF Multiplespecies Animal Productions Systems Project, Harare, Zimbabwe, 1992.

[77] R. D. Z. Taylor, "ZImbabwe," in International Handbook of National Parks and Nature Reserves, C. W. Allin, Ed., pp. 493515, Greenwood Press, Westport, Conn, USA, 1990.

[78] B. Child, Parks in Transition: "Biodiversity, Rural Development and the Bottom Line", Routledge, 2013.

[79] G. Child, "Growth of modern nature conservation in Southern Africa," in Parks in Transition: Biodiversity, Rural Development and the Bottom Line, B. A. Child, Ed., pp. 7-27, Routledge, London, UK, 2013.

[80] D. K. Nyahunzvi, "The resurgence in resource nationalism and private protected areas: through the lens of Save Valley Conservancy's indigenisation," Journal for Nature Conservation, vol. 22, no. 1, pp. 42-49, 2014.

[81] N. Leader-Williams, J. A. Kayera, and G. L. Overton, Tourist Hunting in Tanzania, IUCN Gland, Cambridge, UK, 1996.
[82] A. J. Du Toit, J. V. Rooyen, and J. D. P. Bothma, "Trophy hunting," in Game Ranch Management, J. D. P. Bothma and J. G. D. Toit, Eds., pp. 668-677, Van Schaik, Pretoria, South Africa, 6th edition, 2016.

[83] Canopy, Code of ethics to be observed by professional hunters in Zimbabwe, In: Canopy, Issue no. 2, The house Journal of the Department of National Parks and Wildlife Management, Harare, Zimbabwe, 2001.

[84] E. Gandiwa, I. M. A. Heitkönig, A. M. Lokhorst, H. H. T. Prins, and C. Leeuwis, "Illegal hunting and law enforcement during a period of economic decline in Zimbabwe: a case study of northern Gonarezhou National Park and adjacent areas," Journal for Nature Conservation, vol. 21, no. 3, pp. 133-142, 2013.

[85] N. V. Rooyen and J. D. P. Bothma, "Rifle hunting," in Game Ranch Management, J. D. P. Bothma and J. G. D. Toit, Eds., pp. 679-686, Van Schaik, Pretoria South Africa, 6th edition, 2016.

[86] J. D. P. Bothma, "Bow hunting," in Game Ranch Management, J. D. P. Bothma and J. G. D. Toit, Eds., pp. 686-694, Van Schaik, Pretoria, South Africa, 6th edition, 2016.

[87] P. Bartels, "Darting safaris," in Game Ranch Management, J. D. P. Bothma and J. G. D. Toit, Eds., vol. 6, pp. 709-714, Van Schaik, Pretoria, South Africa, 2016.

[88] M. Greyling, M. McCay, and I. Douglas-Hamilton, "Green hunting as an alternative to lethal hunting," in Proceedings of the Symposium on Human-Elephant Relationships and Conflicts, Colombo, Sri Lanka, 2004.

[89] G. Child, "The emergency of modern nature conservation in Zimbabwe," in Evolution and Innovation in Wildlife Conservation: Parks and Game Ranches to Transfrontier Conservation Areas, H. Suich, B. Child, and A. Spenceley, Eds., pp. 67-84, Earthscan, London, UK, 2012.

[90] M. Stokes, "Population ecology at work: managing game populations," Nature Education Knowledge, vol. 3, article 5, 2012.

[91] C. Fischer, E. Muchapondwa, and T. Sterner, "A bio-economic model of community incentives for wildlife management under CAMPFIRE," Environmental and Resource Economics, vol. 48, no. 2, pp. 303-319, 2011.

[92] M. A. Khumalo, Campfire Monitoring and Evaluation Data, Wwf-Sarpo and the Campfire Association, Harare, Zimbabwe, 2001.

[93] J. O. Ogutu, N. Owen-Smith, H.-P. Piepho, and M. Y. Said, "Continuing wildlife population declines and range contraction in the Mara region of Kenya during 1977-2009," Journal of Zoo$\log y$, vol. 285, no. 2, pp. 99-109, 2011.

[94] P. Bouché, I. Douglas-Hamilton, G. Wittemyer et al., "Will elephants soon disappear from West African Savannahs?" PLoS ONE, vol. 6, no. 6, Article ID e20619, 2011.

[95] N. Muboko, E. Gandiwa, V. Muposhi, and T. Tarakini, "Illegal hunting and protected areas: tourist perceptions on wild animal poisoning in Hwange National Park, Zimbabwe," Tourism Management, vol. 52, pp. 170-172, 2016.

[96] E. Gandiwa, P. Zisadza-Gandiwa, L. Mango, and J. Jakarasi, "Law enforcement staff perceptions of illegal hunting and wildlife conservation in the Gonarezhou National Park, southeast Zimbabwe," Tropical Ecology, vol. 55, no. 1, pp. 119-127, 2014.

[97] W.-G. Crosmary, A. J. Loveridge, H. Ndaimani et al., "Trophy hunting in Africa: long-term trends in antelope horn size," Animal Conservation, vol. 16, no. 6, pp. 648-660, 2013.

[98] R. G. von Brandis and B. K. Reilly, "A temporal analysis of trophy quality in South Africa: has trophy quality changed over time?" South African Journal of Wildlife Research, vol. 37, no. 2, pp. 153$158,2007$. 
[99] R. G. von Brandis and B. K. Reilly, "Spatial variation in trophy quality of popular hunted ungulate species in South Africa," South African Journal of Wildlife Research, vol. 38, no. 1, pp. 1721, 2008.

[100] I. Bond, B. Child, D. D. 1. Harpe, B. Jones, J. Barnes, and H. Anderson, "Private land contribution to conservation in South Africa," in Parks in Transition, B. Child, Ed., pp. 29-61, Earthscan, London, UK, 2004.

[101] M. De Alessi, Private Conservation and Black Rhinos in Zimbabwe: The Save Valley and Bubiana Conservancies, Center for Private Conservation, 2000, https://cei.org/.

[102] P. Lindsey, R. du Toit, A. Pole, and S. Romañach, "Savé Valley conservancy: a large scale african experiment in cooperative wildlife management," in Evolution and Innovation in Wildlife Conservation: Parks and Game Ranches to Transfrontier Conservation Areas, pp. 163-184, 2008.

[103] S. Le Bel, F. Stansfield, M. La Grange, and R. Taylor, "Managing local overabundance of elephants through the supply of game meat: the case of Savé Valley Conservancy, Zimbabwe," South African Journal of Wildlife Research, vol. 43, no. 2, pp. 103-119, 2013.

[104] P. Rosa and P. Joubert, "Entrepreneurial wildlife exploitation in sub-Saharan Africa: an overview," in Tourism and Entrepreneurship: International Perspectives, S. Page and J. Ateljevic, Eds., pp. 173-186, Elsevier, London, UK, 2009.

[105] R. Duffy, Killing for Conservation: Wildlife Policy in Zimbabwe, James Currey, 2000.

[106] S. T. Williams, K. S. Williams, C. J. Joubert, and R. A. Hill, "The impact of land reform on the status of large carnivores in Zimbabwe," PeerJ, vol. 4, Article ID e1537, 2016.

[107] P. Chibisa, A. Ruzive, and T. Mandipa, "The 2000-2004 fast track land reform program and biodiversity issues in the middle save conservancy," Journal of Sustainable Development in Africa, vol. 12, no. 6, pp. 74-100, 2010.

[108] W. Wolmer, "Wilderness gained, wilderness lost: wildlife management and land occupations in Zimbabwe's southeast lowveld," Journal of Historical Geography, vol. 31, no. 2, pp. 260-280, 2005.

[109] C. M. Hamilton, W. E. Thogmartin, V. C. Radeloff et al., "Change in agricultural land use constrains adaptation of national wildlife refuges to climate change," Environmental Conservation, vol. 42, no. 1, pp. 12-19, 2015.

[110] E. Di Minin, N. Leader-Williams, and C. J. Bradshaw, "Banning trophy hunting will exacerbate biodiversity loss," Trends in Ecology \& Evolution, vol. 31, no. 2, pp. 99-102, 2016.

[111] R. D. Baldus, "Wildlife: can pay its way or must be subsidized?" in Best Practices in Sustainable Hunting-A Guide to Best Practices from Around the World, R. D. Baldus, G. R. Damm, and K. Wollscheid, Eds., pp. 12-16, International Council for Game \& Wildlife Conservation, Budakeszi, Hungary, 2008.

[112] J. D. P. Bothma and A. J. Du-Toit, Game Ranch Management, Van Schaik, Pretoria, South Africa, 6th edition, 2016.

[113] ZPWMA, Zimbabwe Parks and Wildlife Management Authority 2014 Annual Report, Zimbabwe Parks and Wildlife Management Authority, Harare, Zimbabwe, 2014.

[114] H. Jachmann, "Monitoring law-enforcement performance in nine protected areas in Ghana," Biological Conservation, vol. 141, no. 1, pp. 89-99, 2008.

[115] C. Packer, A. Loveridge, S. Canney et al., "Conserving large carnivores: dollars and fence," Ecology Letters, vol. 16, no. 5, pp. 635-641, 2013.
[116] P. A. Lindsey, V. R. Nyirenda, J. I. Barnes et al., "Underperformance of African protected area networks and the case for new conservation models: insights from Zambia," PLoS ONE, vol. 9, no. 5, Article ID e94109, 2014.

[117] P. A. Lindsey, "Trophy hunting in sub-Saharan Africa: economic scale and conservation significance," in Best Practices in Sustainable Hunting-A Guide to Best Practices from Around the World, R. D. Baldus, G. R. Damm, and K. Wollscheid, Eds., pp. 4147, International Council for Game and Wildlife Conservation, Budakeszi, Hungary, 2008.

[118] P. J. Balint and J. Mashinya, “CAMPFIRE during Zimbabwe's national crisis: local impacts and broader implications for community-based wildlife management," Society and Natural Resources, vol. 21, no. 9, pp. 783-796, 2008.

[119] S. B. Manyena, A. E. Collins, F. Mudimba, and D. Mudimba, “'Are you serious to ask me about who owns wildlife?' Politics of autonomy over wildlife resources in the Zambezi Valley, Zimbabwe," Forum for Development Studies, vol. 40, no. 1, pp. 87-109, 2013.

[120] E. Di Minin, D. C. Macmillan, P. S. Goodman, B. Escott, R. Slotow, and A. Moilanen, "Conservation businesses and conservation planning in a biological diversity hotspot," Conservation Biology, vol. 27, no. 4, pp. 808-820, 2013.

[121] D. W. Macdonald, P. J. Johnson, A. J. Loveridge, D. Burnham, and A. J. Dickman, "Conservation or the moral high ground: siding with bentham or kant," Conservation Letters, vol. 9, no. 4, pp. 307-308, 2016.

[122] K. M. Dunham, “Trends in populations of elephant and other large herbivores in Gonarezhou National Park, Zimbabwe, as revealed by sample aerial surveys," African Journal of Ecology, vol. 50, no. 4, pp. 476-488, 2012.

[123] K. M. Dunham and A. J. du Toit, "Using citizen-based survey data to determine densities of large mammals: a case study from Mana Pools National Park, Zimbabwe," African Journal of Eco$\log y$, vol. 51, no. 3, pp. 431-440, 2013.

[124] P. A. Lindsey, S. S. Romañach, C. J. Tambling, K. Chartier, and R. Groom, "Ecological and financial impacts of illegal bushmeat trade in Zimbabwe," Oryx, vol. 45, no. 1, pp. 96-111, 2011.

[125] V. K. Muposhi, T. C. Chademana, E. Gandiwa, and N. Muboko, "Edge effects: impact of anthropogenic activities on vegetation structure and diversity in western Umfurudzi Park, Zimbabwe," African Journal of Ecology, vol. 54, no. 4, pp. 450-459, 2016.

[126] C. Mora and P. F. Sale, "Ongoing global biodiversity loss and the need to move beyond protected areas: a review of the technical and practical shortcomings of protected areas on land and sea," Marine Ecology Progress Series, vol. 434, pp. 251-266, 2011.

[127] M. R. W. Rands, W. M. Adams, L. Bennun et al., "Biodiversity conservation: challenges beyond 2010," Science, vol. 329, no. 5997, pp. 1298-1303, 2010.

[128] M. Rukuni, Re-framing the wildlife based land reform programmes in zimbabwe, october, Zimbabwe land series, sokwanele, 2012.

[129] T. Kepe, R. Wynberg, and W. Ellis, "Land reform and biodiversity conservation in South Africa: complementary or in conflict?" International Journal of Biodiversity Science \& Management, vol. 1, no. 1, pp. 3-16, 2005.

[130] R. J. Groom, E. Gandiwa, P. Gandiwa, and H. F. Van Der Westhuizen, "A mass poisoning of white-backed and lappet-faced vultures in Gonarezhou National Park," Honeyguide, vol. 59, no. 1, pp. 5-9, 2013. 
[131] D. L. Ogada, F. Keesing, and M. Z. Virani, "Dropping dead: causes and consequences of vulture population declines worldwide," Annals of the New York Academy of Sciences, vol. 1249, no. 1, pp. 57-71, 2012.

[132] B. M. Croes, P. J. Funston, G. Rasmussen et al., "The impact of trophy hunting on lions (Panthera leo) and other large carnivores in the Bénoué Complex, northern Cameroon," Biological Conservation, vol. 144, no. 12, pp. 3064-3072, 2011.

[133] A. J. Loveridge, A. W. Searle, F. Murindagomo, and D. W. Macdonald, "The impact of sport-hunting on the population dynamics of an African lion population in a protected area," Biological Conservation, vol. 134, no. 4, pp. 548-558, 2007.

[134] R. J. Groom, P. J. Funston, and R. Mandisodza, "Surveys of lions Panthera leo in protected areas in Zimbabwe yield disturbing results: what is driving the population collapse?" ORYX, vol. 48, no. 3, pp. 385-393, 2014.

[135] P. J. N. De Bruyn, M. Landman, C. J. Tambling, and L. Verburgt, "Does science serve the wildlife industry? A critique of von brandis \& Reilly (2008): commentary," South African Journal of Wildlife Research, vol. 39, no. 1, pp. 103-105, 2009.

[136] P. Wilfred, "Trophy hunting and trophy size in ugulla game reserve, western Tanzania," Tanzania Journal of Science, vol. 38, pp. 111-122, 2012.

[137] C. Chomba, R. Senzota, H. Chabwela, and V. Nyirenda, "Lion hunting and trophy quality records in Zambia for the period 1967-2000: will the trends in trophy size drop as lion population declines?" OJE, vol. 4, no. 4, pp. 182-195, 2014.

[138] J. R. Post, M. Sullivan, S. Cox et al., "Canada's recreational fisheries: the invisible collapse?” Fisheries, vol. 27, no. 1, pp. 6-17, 2002.

[139] E. Gandiwa, The numbers game in wildlife conservation: changeability and framing of large mammal numbers in Zimbabwe [Ph.D. thesis], Wageningen University, Wageningen, The Netherlands, 2013.

[140] P. S. Chasek, D. L. Downie, and J. Brown, Global Environmental Politics, Westview Press, 2013.

[141] S. Sarkar and M. Montoya, "Beyond parks and reserves: the ethics and politics of conservation with a case study from Perú," Biological Conservation, vol. 144, no. 3, pp. 979-988, 2011.

[142] L. S. Wyler and P. A. Sheikh, International Illegal Trade in Wildlife: Threats and US Policy, Biblio Gov, 2013.

[143] A. Lavorgna, "Wildlife trafficking in the Internet age," Crime Science, vol. 3, article 5, pp. 1-12, 2014.

[144] L. Wilson-Wilde, "Wildlife crime: a global problem," Forensic Science, Medicine, and Pathology, vol. 6, no. 3, pp. 221-222, 2010.

[145] M. P. Nelson, J. T. Bruskotter, J. A. Vucetich, and G. Chapron, "Emotions and the ethics of consequence in conservation decisions: lessons from cecil the lion," Conservation Letters, vol. 9, no. 4, pp. 302-306, 2016.

[146] P. J. de Beer, The Trophy Hunting Industry of South Africa: A Proposed Model to Ensure its Viable Future, University of Pretoria, Pretoria, South Africa, 2009.

[147] W. Neumann, G. Ericsson, H. Dettki, and J. M. Arnemo, "Effect of immobilizations on the activity and space use of female moose (Alces alces)," Canadian Journal of Zoology, vol. 89, no. 11, pp. 1013-1018, 2011.

[148] G. W. Thiemann, A. E. Derocher, S. G. Cherry, N. J. Lunn, E. Peacock, and V. Sahanatien, "Effects of chemical immobilization on the movement rates of free-ranging polar bears," Journal of Mammalogy, vol. 94, no. 2, pp. 386-397, 2013.

[149] C. Gollier and J. Tirole, "Negotiating effective institutions against climate change," Economics of Energy and Environmental Policy, vol. 4, pp. 5-28, 2015.
[150] B. Buchner and J. Wilkinson, "33 pros and cons of alternative sources of climate change financing and prospects for 'unconventional finance," in Towards a Workable and Effective Climate Regime, vol. 483, 2015.

[151] J. C. Ingram, D. Wilkie, T. Clements et al., "Evidence of Payments for Ecosystem Services as a mechanism for supporting biodiversity conservation and rural livelihoods," Ecosystem Services, vol. 7, pp. 10-21, 2014.

[152] V. K. Muposhi, A. Chanyandura, E. Gandiwa et al., "Post-release monitoring of diet profile and diet quality of reintroduced African buffalo (Syncerus caffer) in Umfurudzi Park, Zimbabwe," Tropical Conservation Science, vol. 7, no. 3, pp. 440-456, 2014.

[153] R. Baldus and A. E. Cauldwell, "Tourist hunting and it's role in development of wildlife management areas in Tanzania," in Proceedings of the 6th International Game Ranching Symposium, Paris, France, July 2004. 

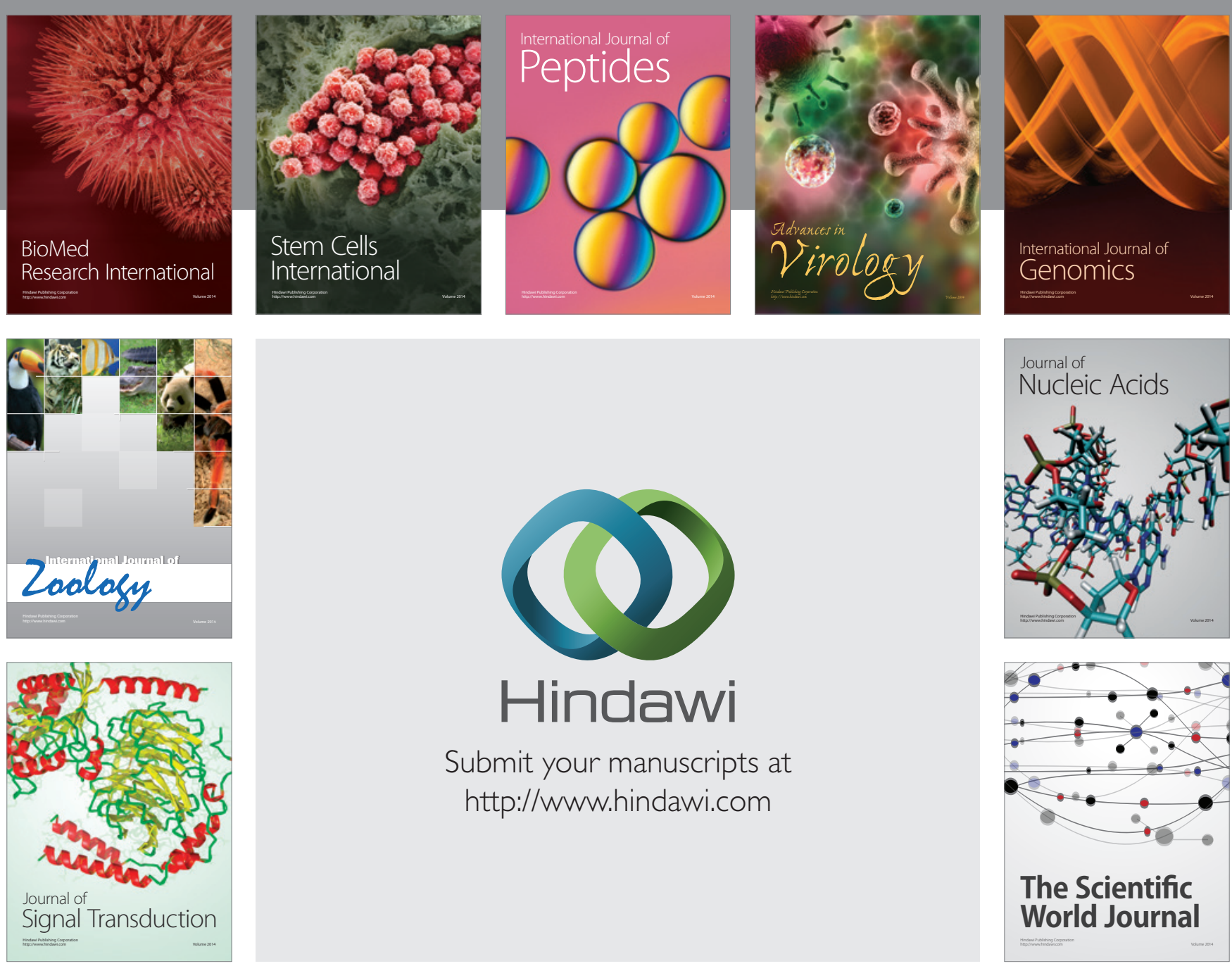

Submit your manuscripts at

http://www.hindawi.com
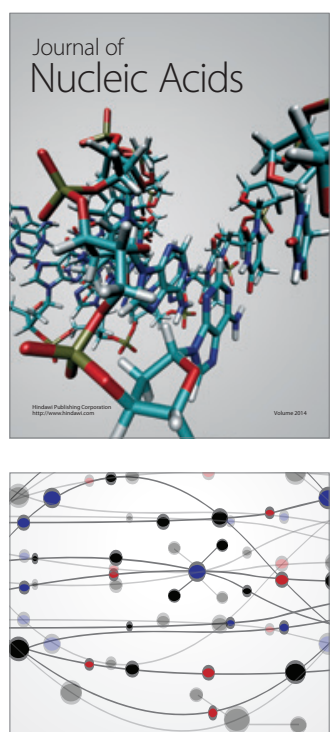

The Scientific World Journal
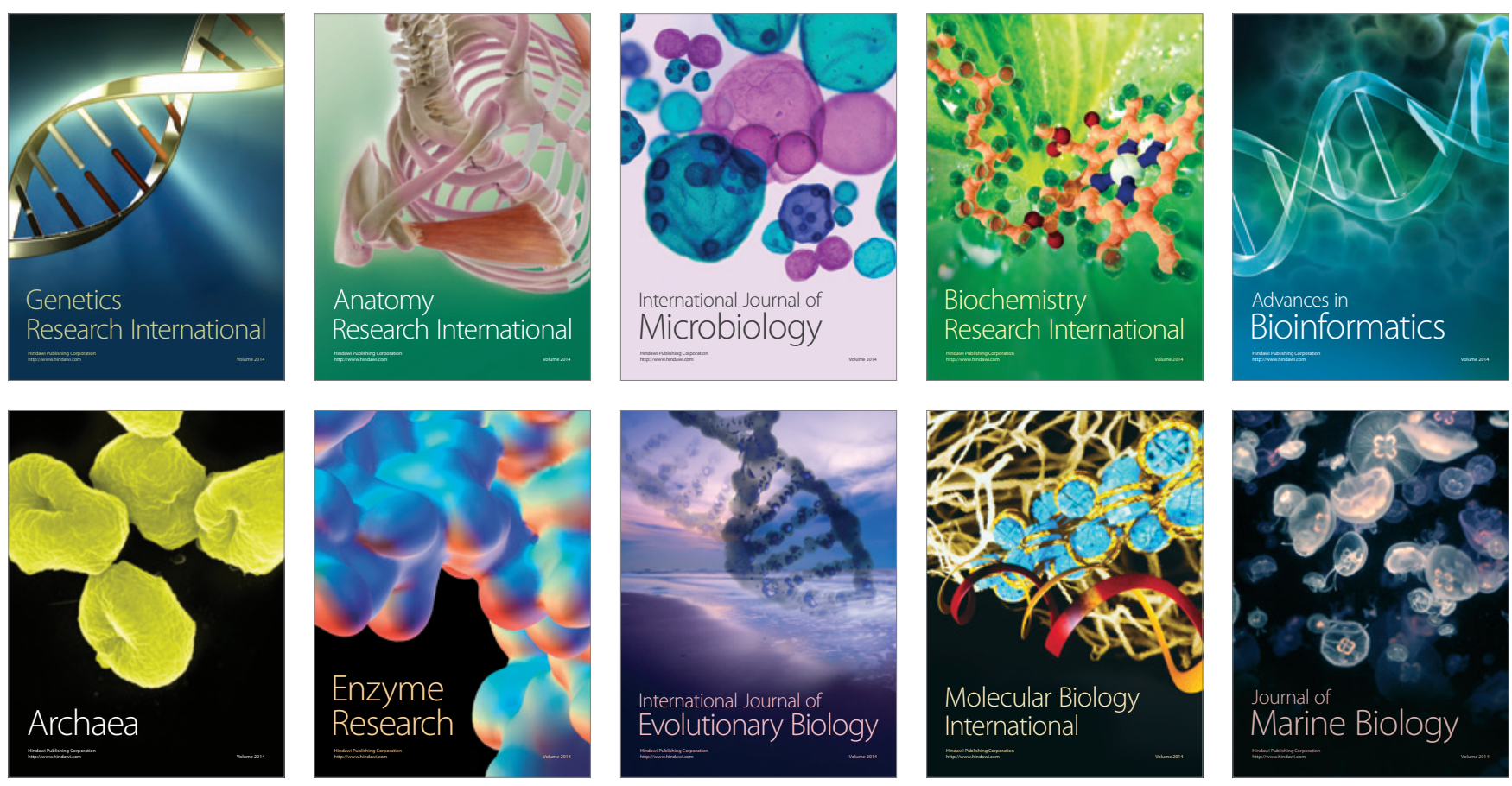